\title{
Development and Thermophysical Profile of Cetyl Alcohol-in-Water Nanoemulsions for Thermal Management ${ }^{\dagger}$
}

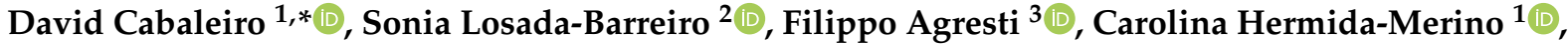 \\ Laura Fedele $^{4, * \mathbb{D}}$, Luis Lugo ${ }^{1} \mathbb{D}$, Simona Barison ${ }^{3} \mathbb{D}$ and Manuel M. Piñeiro ${ }^{1}(\mathbb{D}$ \\ 1 Centro de Investigacións Biomédicas (CINBIO), Departamento de Física Aplicada, Universidade de Vigo, \\ E-36310 Vigo, Spain; cahermida@uvigo.es (C.H.-M.); luis.lugo@uvigo.es (L.L.); mmpineiro@uvigo.es (M.M.P.) \\ 2 Departamento de Química-Física, Universidade de Vigo, E-36310 Vigo, Spain; sonia@uvigo.es \\ 3 CNR ICMATE, Corso Stati Uniti 4, I-35127 Padova, Italy; filippo.agresti@cnr.it (F.A.); \\ simona.barison@cnr.it (S.B.) \\ 4 CNR ITC, Corso Stati Uniti 4, I-35127 Padova, Italy \\ * Correspondence: dacabaleiro@uvigo.es (D.C.); laura.fedele@itc.cnr.it (L.F.); Tel.: +39-049-8295831 (L.F.) \\ + This article is an extended version of our paper presented at 3rd European Symposium on Nanofluids \\ (ESNf2021), Iasi, Romania, 9-10 September 2021.
}

\section{check for}

updates

Citation: Cabaleiro, D.

Losada-Barreiro, S.; Agresti, F.;

Hermida-Merino, C.; Fedele, L.

Lugo, L.; Barison, S.; Piñeiro, M.M. Development and Thermophysical Profile of Cetyl Alcohol-in-Water Nanoemulsions for Thermal Management. Fluids 2022, 7, 11 https://doi.org/10.3390/ fluids7010011

Academic Editor: D. Andrew S. Rees

Received: 29 November 2021

Accepted: 24 December 2021

Published: 29 December 2021

Publisher's Note: MDPI stays neutral with regard to jurisdictional claims in published maps and institutional affiliations.

Copyright: (C) 2021 by the authors. Licensee MDPI, Basel, Switzerland. This article is an open access article distributed under the terms and conditions of the Creative Commons Attribution (CC BY) license (https:// creativecommons.org/licenses/by/ $4.0 /)$

\begin{abstract}
This study focuses on the preparation, thermophysical and rheological characterization of phase change material nanoemulsions as latent functionally thermal fluids. Aqueous dispersions with fine droplets of cetyl alcohol (with a melting temperature at $\sim 321 \mathrm{~K}$ ) were prepared by means of a solvent-assisted method, combining ultrasonication with non-ionic and anionic emulsifiers. Eicosyl alcohol (melting at $\sim 337 \mathrm{~K}$ ) and hydrophobic silica nanoparticles were tested as nucleating agents. Droplet size studies through time and after freeze-thaw cycles confirmed the good stability of formulated nanoemulsions. Phase change analyses proved the effectiveness of eicosyl alcohol to reduce subcooling to a few Kelvin. Although phase change material emulsions exhibited thermal conductivities much larger than bulk cetyl alcohol (at least $60 \%$ higher when droplets are solid), reductions in this property reached $15 \%$ when compared to water. Samples mainly showed desirable Newtonian behavior (or slight shear thinning viscosities) and modifications in density around melting transition were lower than $1.2 \%$. In the case of phase change material nanoemulsions with 8 wt.\% content of dispersed phase, enhancements in the energy storage capacity overcome $20 \%$ (considering an operational temperature interval of $10 \mathrm{~K}$ around solid-liquid phase change). Formulated dispersions also showed good thermal reliability throughout 200 solidification-melting cycles.
\end{abstract}

Keywords: phase change material nanoemulsions (PCMEs); fatty alcohol; stability; subcooling; nucleating agent (NA); energy storage capacity; transport properties

\section{Introduction}

Over last decades, the scarcity of natural energy resources and the effects of energyrelated issues, such as global warming or ozone depletion, have assumed a major role in policy agendas around the world [1]. "Energy Roadmap 2050" is committed to reach European Union's targets of $80-95 \%$ reduction in greenhouse gas emissions relative to 1990 levels by 2050. Meeting those objectives requires decoupling economic growth from fossil fuel-based technologies by lowering the energy consumption and fostering the transition to renewables [2,3]. Thermal energy storage (TES) has proven great potential in energy-saving and the reduction of environmental pollution $[4,5]$. Technologies based on phase change materials (PCMs), absorbing latent heat during melting transition and releasing such thermal energy during crystallization/solidification process are considered among the most effective strategies for energy storage [6]. However, implementation and possible utilization of latent heat approaches at large scale rely on their appropriate integration in thermal facilities. In this sense, phase change material nanoemulsions 
(PCMEs), in which PCMs are dispersed as nanometric-sized droplets in heat transfer fluids, have emerged as a promising option [7]. This type of slurries combines the good heat transfer properties of conventional carrier fluids with the better energy storage density of phase change materials. Additionally, since PCM emulsions exhibit fluid-like behavior (even when droplets are solid or while undergo solid-liquid transition), they can be pumped and can therefore work as both heat transfer and storage media without an additional heat exchanger [8].

In general, most investigations on PCM emulsions used straight-chained alkanes (so-called paraffins) as the dispersed phase [7,9-12]. Such hydrocarbons are inexpensive, hydrophobic and exhibit high latent heats covering a wide range of temperatures (depending on the length of the carbon chain) [6]. Nevertheless, there are numerous alternatives that can be utilized to produce aqueous or nonaqueous PCM emulsions $[13,14]$. Thus, fatty/sugar alcohols or fatty acid (esters) are still relatively unexplored, while they are less toxic than paraffins and can be produced from bio-sourced feedstocks [15-17]. Puupponen et al. [13] prepared fatty acid-in-water nanoemulsions via phase inversion composition using 1-5 wt.\% contents of stearic acid (melting transition $\sim 326 \mathrm{~K}$ ) as the dispersed phase and different mixtures of Span85, SDS and sodium stearate (1:1:1) as surfactants. The authors also attempted to prepare water-based emulsions of myristic acid (another fatty acid melting at $\sim 326 \mathrm{~K}$ ), but the samples presented phase separation after a few days [13]. Fischer et al. [18] formulated an aqueous emulsion using a mixture of two fatty acid esters (containing equal amounts of commercial CrodaTherm ${ }^{\mathrm{TM}} 53$ and CrodaTherm ${ }^{\mathrm{TM}} 47$ ) at a $16 \%$ mass concentration as the dispersed phase and stabilized with 4 wt.\% of two ethoxylated fatty alcohols. Differential scanning calorimetry (DSC) and T-history analyses showed that the apparent specific heat capacity of the sample doubled that of water at around $323 \mathrm{~K}$ [18]. The heat transfer performance of that same emulsion and its potential for advanced temperature management in high voltage electrical devices was experimentally and numerically evaluated in two recent works from the same authors $[19,20]$. When it comes to fatty alcohols such as 1-hexadecanol (also known as cetyl or palmityl alcohol), these materials have proved effective as core for the preparation of micro- [21-25] or nano-encapsulated [26] PCMs. However, to the best of our knowledge, no research has been conducted on the preparation and characterization of aqueous phase change material nanoemulsions using cetyl alcohol as main component of dispersed phase.

There are two major concerns in the development of phase change material nanoemulsions, namely instability and subcooling issues [27]. Nanoemulsions are thermodynamically unfavorable colloidal dispersions. Hence, an appropriate surfactant (or mixture of surfactants) is usually necessary to protect newly formed droplets against different destabilization mechanisms and ensure kinetic stability during storage [28]. When it comes to the industrial implementation of PCM nanoemulsions, samples may be required to be strongly pumped or droplets might need to change from solid to liquid (and vice versa) multiple times [29,30]. The definition of the PCM:surfactant(s):water combination must therefore be carried out on the basis of a careful study of sample stability under various operation conditions. Subcooling or supercooling occurs when a material remains liquid at temperatures below its thermodynamic melting point [31]. Most organic PCMs such as paraffins or fatty alcohols exhibit limited subcooling (no more than a few degrees) in bulk form. However, when scattered in fine droplets or capsules, those materials can behave differently than expected in large volumes. Thus, contrary to bulk systems, heterogeneous nucleation is quite unlikely in nano- or microscopic confinements, and crystal growth is generally slower [32]. This usually results in a reduction of solidification temperature and a more pronounced subcooling effect of PCM slurries. Subcooling (or supercooling) is an undesirable phenomenon in terms of efficiency, since a sample with a large difference between melting and crystallization temperatures may require operating in a wider temperature range to reversibly undergo solid-liquid transition [33]. The use of a nucleating agent (NA) is the most common strategy to promote heterogeneous nucleation and reduce subcooling of dispersed droplets or microcapsules. When it comes to phase change material emulsions, 
micro/nanoparticles [34-40] or other PCMs with melting points higher than that of the main component of the dispersed phase [29,34,41-45] are usually considered as nucleating agents. Huang et al. [32,46] conducted a comprehensive investigation on the influences of surfactant type, nucleating agent and droplet size on the subcooling of paraffin-in-water emulsions. The authors observed that aqueous dispersions containing nanometric particles of $n$-hexadecane showed subcooling degrees of up to $15 \mathrm{~K}$ [32]. However, this phenomenon got considerably reduced when a paraffin wax of a higher melting point was incorporated into the dispersed phase. The potential of (non)-paraffinic materials to work as crystal seeds and trigger the solidification in PCM droplets was further discussed by Günther et al. [47]. Regarding the use of micro- or nanoparticles, interesting results were obtained when using carbonaceous materials such as carbon nanotubes [34,38,40] or graphene oxide [35,48]. Zhao et al. [48] and Barison et al. [35] recently prepared paraffin-in-water emulsions and proved the potential of (reduced) graphene oxide not only as nucleating agent but also as an emulsifier and enhancer of optical properties. Another interesting possibility is the use of hydrophobic nanomaterials [27,39,49]. Thus, Zhang et al. [49] effectively controlled the subcooling of a $20 \mathrm{wt}$ \% $n$-octacosane-in-water emulsion stabilized with Tween $80 / \operatorname{Span} 20$ by means of an optimized $0.3 \mathrm{wt}$.\% concentration of hydrophobic silica (7-40 nm in diameter). Zhang et al. [27,39] also investigated the effect of $\mathrm{SiO}_{2}$ nanoparticles to reduce the subcooling of aqueous emulsions loaded with $30 \mathrm{wt} . \%$ of $n$-hexadecane and stabilized with either Tween/Span [39] or Brij-type [27] surfactants. A 2 wt.\% content of silica particles proved to be really effective to suppress the subcooling of the Tween80/Span80 sample [39]. However, only moderate reductions were measured in the case of emulsions prepared using Brij-type emulsifiers and loaded with 0.5-4 wt.\% contents of hydrophobic silica [27].

In addition to a high storage heat capacity, PCM emulsions are expected to have appropriate heat transfer performance. High dispersed phase contents (generally larger than 20 or $30 \mathrm{wt}$ \%) may lead to strong increases in dynamic viscosity or non-Newtonian behaviors, which, in turn, may render these materials unattractive for thermal applications due to sharp rises in pumping power. Dynamic viscosity and rheological behavior can be considerably affected by the dispersed phase content, surfactant type or the solid/liquid state of dispersed droplets [7]. Shao et al. [30] reported a dynamic viscosity 13 times higher than that of water for a $30 \mathrm{wt}$ \% water dispersion of commercial RT10 stabilized with a mixture of Brij 52 and Tween 60. Zhang et al. [38,49] observed significant differences in dynamic viscosity depending on surfactant type and concentration when investigating $n$-hexadecane-in-water emulsions stabilized with Tween 20, Tween 80 and SDS [38] or $n$-octadecane-in-water samples emulsified with several Tween:Span mixtures [49]. Hence, alongside addressing instability and subcooling issues, a detailed fundamental knowledge of the thermophysical properties and rheological behavior of PCMEs is necessary to understand and evaluate the performance of those novel slurries in thermal systems.

PCMEs are secondary fluids potentially attractive for a wide range of thermal applications requiring high heat storage capacities or energy exchanges under nearly isothermal conditions, such as heating, ventilation and air conditioning (HAVC) or solar harvesting [50,51]. From a technical viewpoint, Rinaldi et al. [52] investigated the applicability of paraffin-in-water emulsions for their use in low-temperature district heating. In comparison to water, the slurry containing PCM droplets with a solid-liquid transition in the range from 313 to $333 \mathrm{~K}$ improved the efficiency of the system and allowed an easier regulation of the operation conditions [52]. PCMEs are also strong candidates in isothermal cooling of electronic devices [7]. In particular, Cao et al. [53] analyzed the potential of paraffin slurries containing $10 \%$ in the mass of commercial OP44E (with a melting at 344-348 K) for thermal management of lithium-ion batteries (the core component of new generation automobiles). That PCME was observed to reach the same cooling performance with a pumping power of only $18.5 \%$ in comparison to water.

In this work, we present the preparation and thermophysical profile of cetyl alcohol-inwater nanoemulsions prepared at 2-8 wt.\% concentrations of the dispersed phase. Sample stability throughout the storage and after freeze-thaw cycles was thoughtfully evaluated 
by visual observation and droplet size measurements using dynamic light scattering. Solid-liquid-phase change transitions were determined in the temperature range from 293 to $353 \mathrm{~K}$, investigating the effectiveness of eicosyl alcohol and hydrophobic $\mathrm{SiO}_{2}$ nanoparticles as nucleating agents to reduce subcooling. The study was completed with dynamic viscosity, thermal conductivity and density measurements to evaluate the effect of the dispersed phase concentration and solid/liquid state of fatty alcohol droplets on those thermophysical properties.

\section{Materials and Methods}

\subsection{Materials}

In order to increase the ionic strength and avoid possible $\mathrm{pH}$ changes that may affect the emulsion stability, a 0.04-M phosphate buffer solution (PBS) was selected as the continuous phase. Appropriate amounts of monobasic sodium phosphate (99\%, Sigma Aldrich, St. Louis, MO, USA) and dibasic sodium phosphate (99\%, Sigma Aldrich) were dissolved in ultra-pure water (produced by a Fisherbrand ${ }^{\mathrm{TM}}$ Accu 20 system, Fisher Scientific, Waltham, $\mathrm{MA}, \mathrm{USA})$ to obtain a $\mathrm{pH}$ value close to 7 . Cetyl alcohol or 1-hexadecanol, $\mathrm{C}_{16} \mathrm{OH},(98 \%$, Alfa-Aesar, Kandel, Germany) was utilized as the phase change material, while eicosyl alcohol or 1-eicosanol, $\mathrm{C}_{20} \mathrm{OH}$, (96\%, Alfa-Aesar, Kandel, Germany) and hydrophobic silica nanoparticles, $\mathrm{SiO}_{2}$ (AEROSIL ${ }^{\circledR} \mathrm{R} 972$, Evonik Degussa $\mathrm{GmbH}$, Essen, Germany) were tested as nucleating agents. Sodium dodecyl sulfate, SDS (98\%, Sigma Aldrich), sodium dodecylbenzenesulfonate, SDBS (technical grade, Sigma Aldrich) and Brij 30 (Fluka, Waltham, MA, USA) were utilized as emulsifiers. $n$-hexane ( $>98.5 \%$, Sigma Aldrich) was used as the solvent during the preparation.

\subsection{Nanoemulsion Formulation and Preparation}

As illustrated in Figure 1, fatty alcohol-in-water emulsions containing 2, 4, 6 and $8 \mathrm{wt} . \%$ of the dispersed phase were formulated following a solvent-assisted method similar to that proposed by Agresti et al. [34]. In order to obtain the PCMEs with small droplets, as well as good fluidity and stability, the effects of the presence and absence of nucleating agent (NA), surfactant type and its mass ratio related to the phase change material on their thermophysical properties were systematically investigated. Specifically, for analyzing the effect of the presence or absence of a nucleating agent and its nature, a series of PCMEs was prepared by employing eicosyl alcohol and hydrophobic $\mathrm{SiO}_{2}$ nanoparticles as nucleating agents at the mass ratios of 9:1 $\left(\mathrm{C}_{16} \mathrm{OH}: \mathrm{C}_{20} \mathrm{OH}\right)$ and 49:1 $\left(\mathrm{C}_{16} \mathrm{OH}: \mathrm{SiO}_{2}\right)$. The impact of using mixed surfactants (SFT) on the formation and stability of PCMEs were also explored. Based on the below results (Section 3.1), the combination of SDS, Brij 30 and SDBS at the optimal mass ratio was chosen for the following experiments.

Brij 30 and the dispersed phase (cetyl alcohol + nucleating agents) were dissolved in $n$-hexane (at a dispersed phase:solvent mass ratio of 1:5), while SDS and SDBS were mixed with water. Both solutions were sonicated separately and then joined together at $333 \mathrm{~K}$ in a low-power ultrasound bath (Ultrasons-HD J.P. Selecta S.A., Barcelona, Spain) operating with an ultrasonic pulse of $40 \mathrm{kHz}$ and an out power of $120 \mathrm{~W}$. The mixture was then further sonicated for 12 min using an ultrasound probe (Bandelin Sonopuls HD 2200, Bandelin electronic $\mathrm{GmbH}$, Berlin, Germany) together with a 13-mm-diameter titanium tip, operating at $20 \mathrm{kHz}$ with an amplitude of $60 \%$ and an on:off pulse method of 50\%:50\%. Finally, the sample was maintained at 353-363 K under magnetic stirring for 2 to $3 \mathrm{~h}$ to evaporate the solvent ( $n$-hexane).

Dispersed droplets sizes, polydispersity indices (pdi) and ¿eta potentials were analyzed by dynamic light scattering (DLS) using a Malvern Zetasizer Nano ZS (Malvern Instruments Ltd., Malvern, UK) [54]. The device is equipped with a 4-mW He/ Ne laser emitting $633 \mathrm{~nm}$. Scattering intensity measurements were conducted with a $173^{\circ}$ angle relative to the source using plastic cuvettes/capillary cells. Intensity autocorrelation functions were analyzed by a General Purpose Algorithm (integrated into the Malvern Zetasizer software), and the hydrodynamic droplet sizes were approximated as the effective Z-average 
diameters from the bimodal size distribution [55]. Reported values are the average of at least three parallel measurements of 15 runs each.

a)
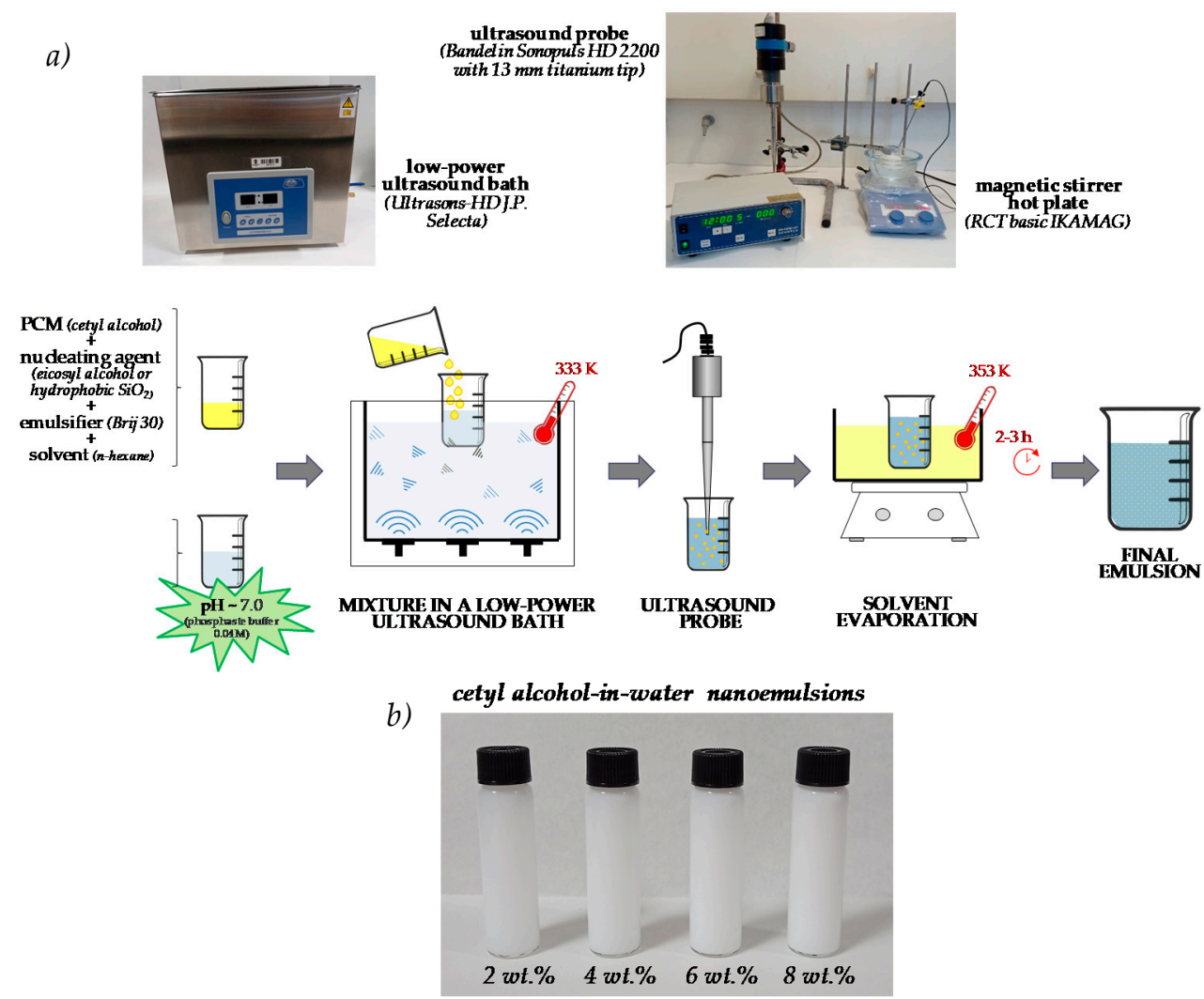

Figure 1. (a) Major steps of the solvent-assisted method used for the formulation of cetyl alcohol-inwater nanoemulsions, and (b) images of prepared fatty alcohol-in-water nanoemulsions containing 2 , 4,6 and 8 wt.\% of dispersed phase without a nucleating agent.

\subsection{Thermophysical Profile}

Solid-liquid transitions of bulk cetyl alcohol and prepared emulsions were investigated by means of a differential scanning calorimeter, DSC, Q2000 (TA Instruments, New Castle, WA, USA) equipped with a RSC90 refrigerated cooling system. About ten micrograms of sample were hermetically encapsulated in $20-\mu \mathrm{L}$ Tzero ${ }^{\mathrm{TM}}$ aluminum pans, and a nitrogen stream (flow rate: $50 \mathrm{~mL} \cdot \mathrm{min}^{-1}, \mathrm{~N}_{2}$ mole fraction purity $>0.99999$ ) was flushed through the DSC chamber to create an inert atmosphere. Cooling and heating thermograms in the temperature range from 293 to $353 \mathrm{~K}$ were determined at $1-5 \mathrm{~K} \cdot \mathrm{min}^{-1}$ scanning rates. The experimental uncertainties were estimated to be $0.3 \mathrm{~K}$ (with a repeatability of $0.1 \mathrm{~K}$ ) and $1.2 \mathrm{~J} \cdot \mathrm{g}^{-1}$ (repeatability of $0.7 \mathrm{~J} \cdot \mathrm{g}^{-1}$ ) for the transition temperatures and latent heats, respectively [56].

Thermal conductivities, $\lambda$, were obtained in the temperature interval from 283 to $333 \mathrm{~K}$ using a THW-L2 device (Thermtest Inc., Richibucto Road, Hanwell, NB, Canada) based on the transient short hot-wire method [57]. Measurements were conducted using a standard THW-L2 probe consisting of an uninsulated alumel wire with a length of $60 \mathrm{~mm}$ and a diameter of about $0.1 \mathrm{~mm}$. The sensor was vertically immersed in the tested liquid, which completely surrounded the probe so that heat could freely diffuse in all directions. Both sample and probe were contained in a specially build block maintained under isothermal conditions using a dry bath supplied by the manufacturer. Thermal powers between 150 and $190 \mathrm{~mW}$ and a power input time of $1 \mathrm{~s}$ were selected to reach a temperature rise of $\sim 2 \mathrm{~K}$ in the investigated samples. An experimental uncertainty better than $4 \%$ was assumed for this property. More details regarding the experimental device and calibration can be found in References [57,58]. 
Dynamic viscosity, $\mu$, was investigated in the temperature range from 283 to $333 \mathrm{~K}$ by means of a Physica MR-101 rotational rheometer (Anton Paar, Graz, Austria) working with a coaxial-cylinder geometry consisting of a CC27/T200/SS cup (inner diameter: $28.9 \mathrm{~mm}$ ) and a B-CC27 / P6 bob (outer diameter: $26.7 \mathrm{~mm}$ ). The sample temperature was controlled to within $0.1 \mathrm{~K}$ by a C-PTD200 cylinder Peltier system. Viscosity flow curves were collected at shear rates logarithmically increasing from 1 to $100 \mathrm{~s}^{-1}$ with at least 5 points per decimal. The declared uncertainty of the shear viscosity measurements with this device and geometry was better than $4 \%$.

Densities, $\rho$, were determined in the temperature range from 283 to $353 \mathrm{~K}$ using a vibrating U-tube densimeter (DMA 4500, Anton Paar, Austria). The obtained values with this instrument had an uncertainty of $5 \cdot 10^{-4} \mathrm{~g} \cdot \mathrm{cm}^{-3}$ [59].

\section{Results}

\subsection{Optimization of Emulsion Composition and Stability}

The SDS surfactant proved to be effective for the preparation of various paraffin-inwater emulsions using a solvent-assisted method $[33,35,60]$. However, when emulsifying $n$-alkanols such as cetyl or stearyl alcohols in aqueous solutions of SDS or cetyltrimethylammonium chloride (CTAC), the association of the fatty alcohol with those ionic surfactants may lead to the formation of lamellar and vesicular gel networks once samples are cooled down below the melting point of the fatty alcohol [61-64]. Thus, unlike $n$-alkanes, the slightly polar head of $n$-alkanols and their straight carbon chain induce head-to-head and tail-to-tail interactions between these types of surfactants and fatty alcohols, allowing them to be integrated in lamellar-type networks [65]. Such multiphase colloidal structures (also called " $\alpha$-gel") contain bilayers made of hexagonally-packed crystals of surfactants and fatty alcohols, which give rise to a creamy texture of the sample [62], which is uninteresting for heat transfer applications. Those gels, whose main binding forces are electrostatic in nature [61], were not observed for cetyl alcohol-in-water emulsions prepared using nonionic polyoxylated surfactants [66], for example. In order to reduce the interactions between cetyl alcohol and SDS, in our present study, we limited SDS:dispersed phase ratio to 1:80 (in mass) and incorporated a nonionic Brij 30 into the emulsions. Like SDS, Brij 30 also has a 12-carbon aliphatic chain as a lipophilic tail. However, the hydrophilic forces of Brij 30 head are not electrostatic in nature, and the hydrophilic lipophilic balance (HLB = 9.7) is considerably lower than SDS (usually considered HLB = 40 [17]). Thus, Brij 30 molecules would tend to avoid water more than SDS, which may be appropriate to disrupt the formation of possible lamellar/vesicular aggregates and network structures. Finally, in order to rise the repulsive electrostatic charges among dispersed droplets and avoid instability issues such as coalescence, a small amount of SDBS was also incorporated to the surfactant mixture. SDBS $(\mathrm{HLB}=10.6)$ is another anionic surfactant based on the same dodecyl chain of SDS but also containing a strong hydrophobic benzene group.

In our present study, the composition and concentration of the surfactant mixture used to prepare the emulsions were optimized based on dynamic light scattering (DLS) analyses. Thus, a surfactant:dispersed phase mass ratio of 1:8 using an SDS:SDBS:Brij 30 mixture with a mass proportion of 10\%:10\%:80\% was defined in order to ensure average hydrodynamic

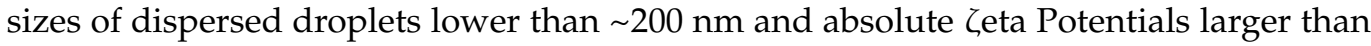
$40 \mathrm{mV}$. The DLS results measured at $298.15 \mathrm{~K}$ for some representative nanoemulsions are gathered in Table 1.

One day after preparation, nanoemulsions formulated using 2-8 $\mathrm{wt} \%$ contents of fatty alcohols as the dispersed phase exhibited average droplet diameters in the range 100-160 nm and polydispersity indices of 0.2 to 0.3 . In the case of samples containing $\mathrm{SiO}_{2}$ nanoparticles, the droplets were less polydisperse (pdi $=0.1-0.2$ ) but $\sim 50 \mathrm{~nm}$ larger. All investigated concentrations showed negative Ceta potentials in the range from -40 to $-70 \mathrm{mV}$, which are, in the absolute value, above the $\pm 30-\mathrm{mV}$ threshold usually considered for good stability in colloids [67]. 
Table 1. Ceta potentials ${ }^{\dagger}$, hydrodynamic diameters * and polydispersity indices (pdi) of cetyl alcohol-in-water nanoemulsions at $298.15 \mathrm{~K} \ddagger$.

\begin{tabular}{|c|c|c|c|c|c|}
\hline \multicolumn{3}{|c|}{ Main Formulation Parameters } & \multicolumn{2}{|l|}{ 1st Day } & \multirow{2}{*}{$\begin{array}{l}\text { 30th Day } \\
\text { Size (pdi) }\end{array}$} \\
\hline $\begin{array}{l}\mathrm{C}_{16} \mathrm{OH} \\
\text { (Final wt. \%) }\end{array}$ & $\begin{array}{l}\text { Nucleating Agent } \\
\text { (Final wt.\%) }\end{array}$ & $\begin{array}{l}\text { SDS + SDBS + Brij } 30 \\
\text { (Final wt.\%) }\end{array}$ & $\begin{array}{l}\text { Ceta } \\
\text { Potential }\end{array}$ & Size (pdi) & \\
\hline 2 wt. $\%$ & - & 0.25 wt. $\%$ & $-44 \mathrm{mV}$ & $107 \mathrm{~nm}(0.25)$ & $106 \mathrm{~nm}(0.21)$ \\
\hline 4 wt.\% & - & 0.50 wt. $\%$ & $-56 \mathrm{mV}$ & $123 \mathrm{~nm}(0.24)$ & $124 \mathrm{~nm}(0.21)$ \\
\hline 6 wt. $\%$ & - & 0.75 wt. $\%$ & $-63 \mathrm{mV}$ & $123 \mathrm{~nm}(0.24)$ & $121 \mathrm{~nm}(0.21)$ \\
\hline 8 wt. $\%$ & - & 1.00 wt. $\%$ & $-68 \mathrm{mV}$ & $152 \mathrm{~nm}(0.30)$ & $168 \mathrm{~nm}(0.41)$ \\
\hline 1.8 wt. $\%$ & $\mathrm{C}_{20} \mathrm{OH}(0.2$ wt. $\%)$ & 0.25 wt. $\%$ & $-46 \mathrm{mV}$ & $102 \mathrm{~nm}(0.22)$ & $106 \mathrm{~nm}(0.22)$ \\
\hline 3.6 wt. $\%$ & $\mathrm{C}_{20} \mathrm{OH}(0.4$ wt. $\%)$ & 0.50 wt. $\%$ & $-54 \mathrm{mV}$ & $126 \mathrm{~nm}(0.28)$ & $131 \mathrm{~nm}(0.30)$ \\
\hline 5.4 wt. $\%$ & $\mathrm{C}_{20} \mathrm{OH}(0.6$ wt. $\%)$ & 0.75 wt. $\%$ & $-62 \mathrm{mV}$ & $139 \mathrm{~nm}(0.31)$ & $160 \mathrm{~nm}(0.36)$ \\
\hline 7.2 wt. $\%$ & $\mathrm{C}_{20} \mathrm{OH}(0.8$ wt. $\%)$ & $1.00 \mathrm{wt} . \%$ & $-66 \mathrm{mV}$ & $162 \mathrm{~nm}(0.31)$ & $176 \mathrm{~nm}(0.36)$ \\
\hline 1.96 wt. $\%$ & $\mathrm{SiO}_{2}(0.04$ wt. $\%)$ & 0.25 wt. $\%$ & $-42 \mathrm{mV}$ & $152 \mathrm{~nm}(0.14)$ & $157 \mathrm{~nm}(0.17)$ \\
\hline 3.92 wt. $\%$ & $\mathrm{SiO}_{2}(0.08$ wt. $\%)$ & 0.50 wt. $\%$ & $-50 \mathrm{mV}$ & $173 \mathrm{~nm}(0.17)$ & $178 \mathrm{~nm}(0.17)$ \\
\hline 5.88 wt. $\%$ & $\mathrm{SiO}_{2}(0.12$ wt.\%) & 0.75 wt. $\%$ & $-61 \mathrm{mV}$ & $186 \mathrm{~nm}(0.19)$ & $189 \mathrm{~nm}(0.18)$ \\
\hline 7.84 wt. $\%$ & $\mathrm{SiO}_{2}(0.16$ wt. $\%)$ & 1.00 wt. $\%$ & $-68 \mathrm{mV}$ & $214 \mathrm{~nm}(0.21)$ & $220 \mathrm{~nm}(0.21)$ \\
\hline
\end{tabular}

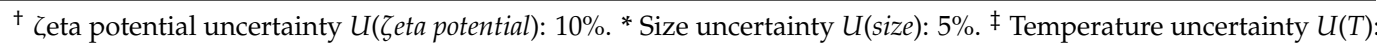
$0.02 \mathrm{~K}$.

The DLS droplet size measurements were monitored over a month and after several solidification-melting cycles to rule out possible destabilization issues under static conditions and when droplets undergo solid-liquid phase change. Figure 2a shows the temporal evolution of hydrodynamic diameters when emulsions are stored under static conditions during a month. The prepared samples exhibited only slight increases in the size of dispersed droplets (lower than $\sim 20-30 \mathrm{~nm}$ ). As presented in Figure $2 \mathrm{~b}$, no significant change was observed in the studied emulsions when the droplets were subject to 25 freeze-thaw cycles covering the temperature range between 283 and $333 \mathrm{~K}$.

$\square \quad \mathrm{C}_{16} \mathrm{OH}(4 \mathrm{wt} . \%) /$ water

- $\mathrm{C}_{16} \mathrm{OH}(3.6 \mathrm{wt} . \%)+\mathrm{C}_{20} \mathrm{OH}(0.4 \mathrm{wt} . \%) /$ water

- $\mathrm{C}_{16} \mathrm{OH}(3.92 \mathrm{wt} . \%)+\mathrm{SiO}_{2}(0.08 \mathrm{wt} . \%) /$ water

$\diamond \mathrm{C}_{16} \mathrm{OH}(8 \mathrm{wt} . \%) /$ water $\triangle \mathrm{C}_{16} \mathrm{OH}(2$ wt.\%)/water
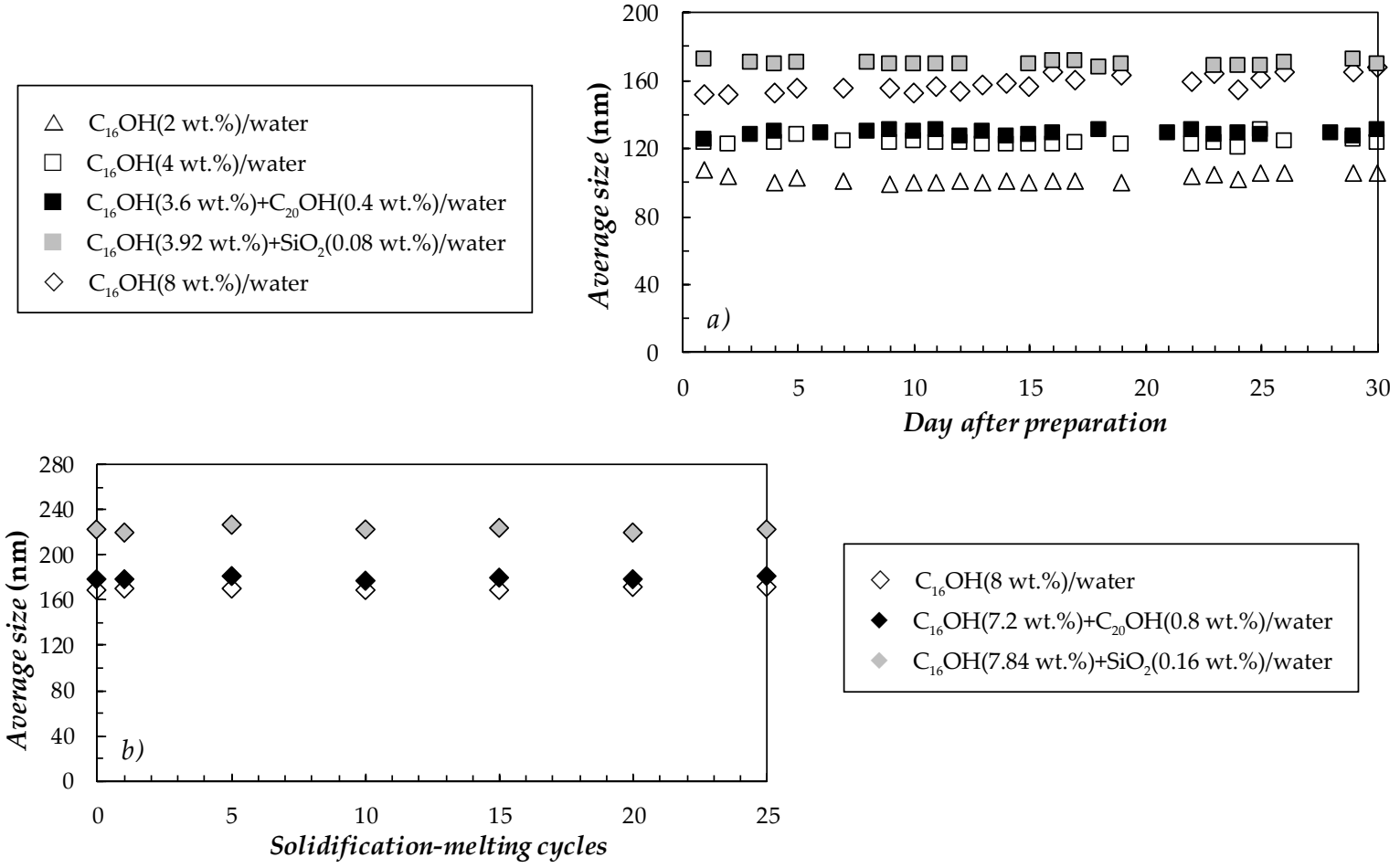

Figure 2. Evolution of the droplet average size: (a) throughout storage under static conditions and (b) after solidification-melting cycles for some representative emulsions. 


\subsection{Phase Change Chracteristics}

Crystallization and melting transitions of bulk cetyl alcohol and fatty alcohol emulsions were investigated in the temperature range from 293 to $353 \mathrm{~K}$. The cooling and heating thermograms are presented in Figure 3, while the corresponding phase change enthalpies and temperatures are summarized in Table 2. As usual in the case of long-chain fatty alcohols, two exothermic transitions are observed in the cooling scan of the bulk $\mathrm{C}_{16} \mathrm{OH}$ (Figure 3a). The first thermal event (at $\sim 321.6 \mathrm{~K}$ ) corresponds to the transformation from liquid to a hexagonally packed solid and the other (at $\sim 316.4 \mathrm{~K}$ ) to a polymorphic change from the hexagonal to orthorhombic crystalline phase $[65,68-70]$. The DSC heating curve of the bulk $\mathrm{C}_{16} \mathrm{OH}$ presents a single endothermic peak of $212.7 \mathrm{~J} \cdot \mathrm{g}^{-1}$ at $\sim 321.9 \mathrm{~K}$ corresponding to the melting of the alkanol (Figure $3 \mathrm{~b}$ ). The obtained melting results agree with the ranges of fusion latent heats $\left(204-240 \mathrm{~J}^{-\mathrm{g}^{-1}}\right)$ and temperatures $(\sim 322-323 \mathrm{~K})$ usually reported for pure cetyl alcohol $[23,71-76]$.

Table 2. Phase change characteristics of bulk $\mathrm{C}_{16} \mathrm{OH}$ alkanol and $\mathrm{C}_{16} \mathrm{OH}$-in-water emulsions obtained at low scanning rates ${ }^{\dagger}$.

\begin{tabular}{|c|c|c|c|c|c|}
\hline \multicolumn{3}{|c|}{ Main Formulation Parameters } & \multirow{2}{*}{$\begin{array}{l}\text { Cooling } \\
T(\mathrm{~K}) \ddagger\end{array}$} & \multicolumn{2}{|l|}{ Heating } \\
\hline $\begin{array}{l}\mathrm{C}_{16} \mathrm{OH} \\
\text { (Final wt.\%) }\end{array}$ & $\begin{array}{l}\text { Nucleating Agent } \\
\text { (Final wt.\%) }\end{array}$ & $\begin{array}{l}\text { SDS + SDBS + Brij30 } \\
\text { (Final wt. } \% \text { ) }\end{array}$ & & $T(\mathrm{~K}) \ddagger$ & $\Delta h\left(\mathrm{~J} \cdot \mathrm{g}^{-1}\right)$ * \\
\hline bulk $\mathrm{C}_{16} \mathrm{OH}$ & & & $321.6 / 316.4$ & 321.9 & 212.7 \\
\hline 2 wt. $\%$ & - & 0.25 wt. $\%$ & $311.3 / 306.6^{\mathrm{p}}$ & 319.9 & 2.75 \\
\hline 4 wt.\% & - & 0.50 wt. $\%$ & $312.1 / 306.4 \mathrm{p}$ & $320.1 / 327.6^{p}$ & 5.64 \\
\hline 6 wt. $\%$ & - & 0.75 wt. $\%$ & $313.4 / 308.3 \mathrm{p} / 305.5 \mathrm{p}$ & $320.9 / 327.4 \mathrm{p}$ & 8.06 \\
\hline 8 wt. $\%$ & - & 1.00 wt. $\%$ & $312.9 / 308.1 \mathrm{p} / 305.9 \mathrm{p}$ & $320.3 / 327.2 \mathrm{p}$ & 11.54 \\
\hline 1.8 wt. $\%$ & $\mathrm{C}_{20} \mathrm{OH}(0.2$ wt. $\%)$ & 0.25 wt. $\%$ & $320.3 / 314.5 \mathrm{p}$ & $320.6 / 328.8 \mathrm{p}$ & 2.46 \\
\hline $3.6 \mathrm{wt} . \%$ & $\mathrm{C}_{20} \mathrm{OH}(0.4$ wt. $\%)$ & 0.50 wt. $\%$ & $320.4 / 314.6^{\mathrm{p}}$ & $320.7 / 328.9 p$ & 5.33 \\
\hline 5.4 wt. $\%$ & $\mathrm{C}_{20} \mathrm{OH}(0.6$ wt. $\%)$ & 0.75 wt. $\%$ & $320.5 / 314.8^{p}$ & $320.5 / 329.0 \mathrm{p}$ & 7.46 \\
\hline 7.2 wt. $\%$ & $\mathrm{C}_{20} \mathrm{OH}(0.8$ wt. $\%)$ & 1.00 wt. $\%$ & $320.8 / 315.0 \mathrm{p}$ & $320.4 / 328.8^{p}$ & 10.88 \\
\hline 1.96 wt. $\%$ & $\mathrm{SiO}_{2}(0.04$ wt. $\%)$ & 0.25 wt. $\%$ & 313.7 & 320.0 & 2.35 \\
\hline 3.92 wt. $\%$ & $\mathrm{SiO}_{2}(0.08$ wt.\%) & 0.50 wt. $\%$ & 313.5 & $320.1 / 323.5 \mathrm{p}$ & 5.20 \\
\hline 5.88 wt. $\%$ & $\mathrm{SiO}_{2}(0.12$ wt.\%) & 0.75 wt. $\%$ & 313.4 & $320.0 / 323.0 \mathrm{p}$ & 7.22 \\
\hline 7.84 wt. $\%$ & $\mathrm{SiO}_{2}(0.16$ wt.\%) & 1.00 wt. $\%$ & 313.3 & $320.2 / 323.1^{p}$ & 10.01 \\
\hline
\end{tabular}

${ }^{+}$Bulk $\mathrm{C}_{16} \mathrm{OH}$ phase change characteristics were obtained from $\beta=1 \mathrm{~K} \cdot \mathrm{min}^{-1}$ thermograms. In the case of nanoemulsions, determinations were made from the scans at $\beta=2 \mathrm{~K} \cdot \mathrm{min}^{-1}$ in order to ensure a better accuracy. p Peak temperatures. ${ }^{\ddagger}$ Temperature uncertainty $U(T): 0.3 \mathrm{~K} .{ }^{*}$ Enthalpy uncertainty $U(\Delta h): 1.2 \mathrm{~K} \mathrm{~J} \cdot \mathrm{g}^{-1}$.

In the case of $\mathrm{C}_{16} \mathrm{OH}$-in-water emulsions prepared without any nucleating agent (Figure $3 \mathrm{c}, \mathrm{d})$, the onset temperature of melting transition was slightly lower $(\sim 1-2 \mathrm{~K})$ than the corresponding value of the bulk fatty alcohol. A larger difference between onset and end set temperatures (with two superimposed endothermic peaks) is also observed in the case of $\mathrm{C}_{16} \mathrm{OH}$-in-water nanoemulsions. A similar two-peak behavior was also reported for solid-liquid particles of cetyl alcohol by Diniz et al. [66]. This larger difference between the onset and end set temperatures may be attributed to the difficulty in forming crystalline arrangements in confined spaces, which leads to a larger disorder of fatty alcohol crystals [66]. 

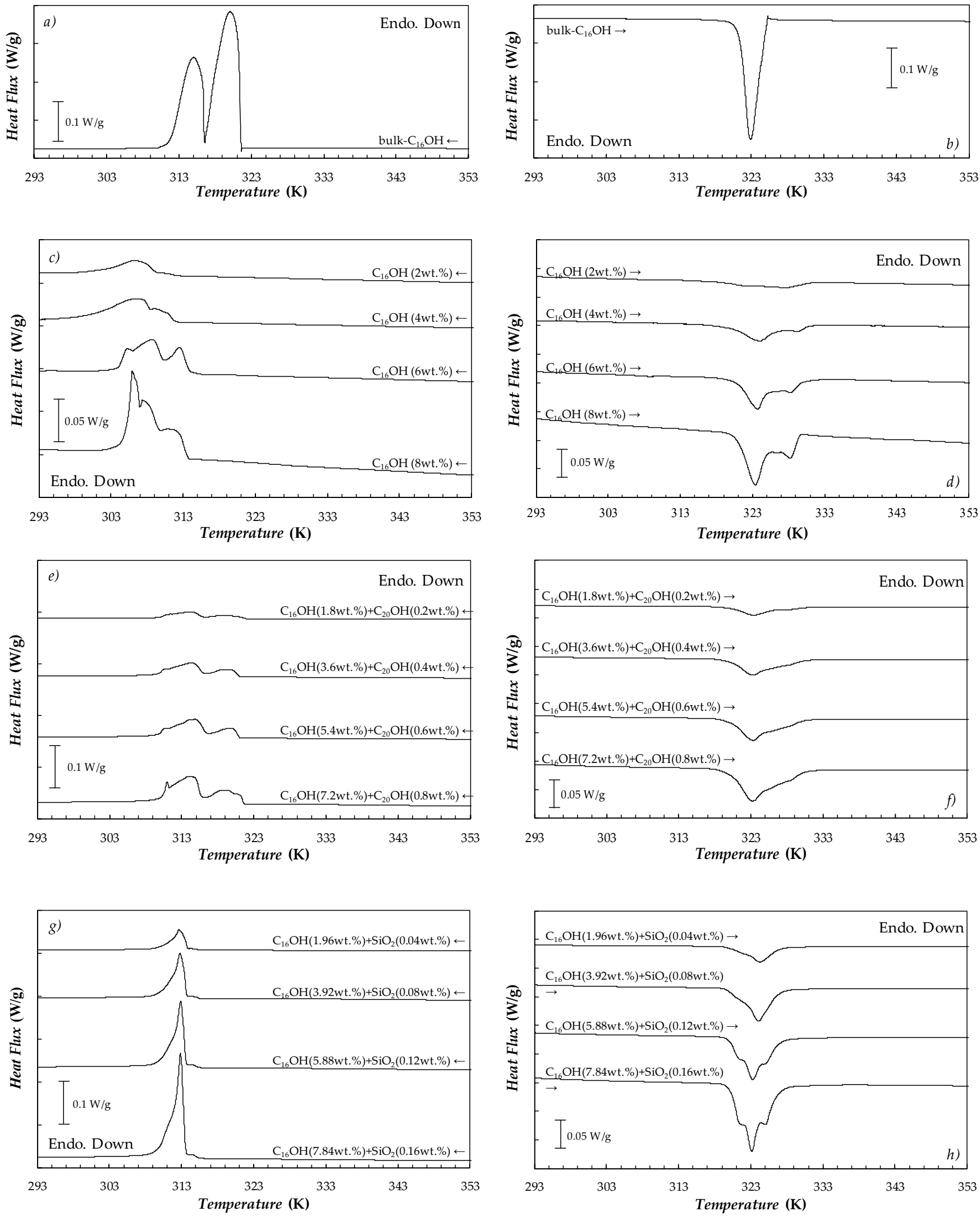

Figure 3. (a,c,e,g) Cooling and (b,d,f,h) heating DSC thermograms measured at $\beta=2 \mathrm{~K} \cdot \mathrm{min}^{-1}$ for $(\mathbf{a}, \mathbf{b})$ bulk $\mathrm{C}_{16} \mathrm{OH}$ alkanol and (c,d) PCM emulsions. 
The latent heat of nanoemulsions $\triangle h_{\text {latent, } P C M E}$ improves with the rising content of dispersed droplets. However, those values are about $65-69 \%$ the values expected according to the following mass relation:

$$
\Delta h_{\text {latent, } P C M E}=\varphi_{P C M} \cdot \Delta h_{\text {latent, } P C M}
$$

where $\Delta h_{\text {latent }}$ is the latent heat, $\varphi$ is the mass fraction and PCM and PCME stand for the phase change material and phase change material emulsion, respectively. The latent heats up to $10-40 \%$ lower than predicted by Equation (1) were also reported in the literature for paraffin-in-water nanoemulsions $[33,34,49]$ or other materials when confined in nanopores $[77,78]$. These reductions may be attributed to the fact that, in dispersions with fine droplets, a significant portion of PCM is taking part of the surface layer, which considerably reduces the crystal fraction (in comparison to the bulk situation) [34,47].

Larger shifts in the temperature can be observed when comparing the cooling thermograms of bulk cetyl alcohol and cetyl alcohol-in-water emulsions without any nucleating agent. Thus, while the subcooling (difference between onset temperatures in melting and solidification) is less than $\sim 1 \mathrm{~K}$ in the case of bulk $\mathrm{C}_{16} \mathrm{OH}$, this value is up to $\sim 10 \mathrm{~K}$ in $\mathrm{C}_{16} \mathrm{OH}$-in-water emulsions. Contrary to bulk systems, in emulsified samples, crystal growth is restricted by the droplet surface. Since all isolated PCM droplets are unlikely to unintentionally contain impurities or non-homogeneities, in such shrinking volumes, crystallization is usually dominated by homogeneous nucleation.

In order to try to reduce the subcooling of cetyl alcohol-in-water emulsions, two nucleating agents were tested, namely eicosyl alcohol, $\mathrm{C}_{20} \mathrm{OH}$, (another PCM with a higher melting temperature than the main component of the dispersed phase) and hydrophobic silica nanoparticles, $\mathrm{SiO}_{2}$. In this investigation, the $\mathrm{C}_{16} \mathrm{OH}: \mathrm{C}_{20} \mathrm{OH}$ and $\mathrm{C}_{16} \mathrm{OH}: \mathrm{SiO}_{2}$ ratios were fixed at 9:1 and 49:1, respectively. No further contents of the nucleating agents were considered to avoid important reductions of latent heat and further rises in dynamic viscosity (in the case of samples containing silica nanoparticles) $[39,79]$. Regarding $\mathrm{C}_{16} \mathrm{OH}$ $+\mathrm{C}_{20} \mathrm{OH} / \mathrm{W}$ emulsions (see Figure 3e,f), the fatty alcohol proved to be a good nucleating agent to trigger heterogeneous nucleation. Thus, even if the presence of $\mathrm{C}_{20} \mathrm{OH}$ did not considerably affect the melting transition, the freezing process shifted towards higher temperatures (in comparison to emulsions only containing $\mathrm{C}_{16} \mathrm{OH}$ as dispersed phase). As for the $\mathrm{C}_{16} \mathrm{OH}+\mathrm{SiO}_{2} / \mathrm{W}$ system (Figure $3 \mathrm{~g}$,h), even if dispersed droplets underwent solid-liquid transition in a shorter temperature range (when compared to $\mathrm{C}_{16} \mathrm{OH} / \mathrm{W}$ or $\mathrm{C}_{16} \mathrm{OH}+\mathrm{C}_{20} \mathrm{OH} / \mathrm{W}$ samples), the onset temperature of solidification was similar to that of $\mathrm{C}_{16} \mathrm{OH} / \mathrm{W}$ emulsions.

\subsection{Heat Storage Capacity}

The thermal energy stored by a PCM emulsion, $\Delta h_{\text {total, } P C M E}$, in a temperature interval in which dispersed droplets undergo solid-liquid phase change, $\Delta T$, can be calculated as:

$$
\Delta h_{\text {total, } P C M E}=\left[\varphi_{P C M} \cdot c_{p}, P C M+\left(1-\varphi_{P C M}\right) \cdot c_{p, C F}\right] \cdot \Delta \mathrm{T}+\Delta h_{\text {latent }, P C M E}
$$

where $\Delta h_{\text {latent }}$ is the latent heat; $\varphi$ is the mass fraction; $c_{p}$ is the isobaric heat capacity and PCM, CF and PCME subscripts stand for phase change material, carrier fluid and phase change material emulsion, respectively. Given the minor contributions of surfactants and nucleating agents to the total heat storage capacity of emulsions, their isobaric heat capacities were assumed equal to those of the main component of dispersed phase (cetyl alcohol), as also done in Reference [43]. Calculations were made using the latent heats gathered in Table 2 and the isobaric heat capacities reported in the literature for water [80] and cetyl alcohol. Figure 4 presents the enhancement in heat storage capacity (regarding water) for some cetyl alcohol nanoemulsions formulated with and without a nucleating agent. The enhancement in the stored thermal energy reduces with the increasing temperature interval considered for the calculation. Improvements in the heat storage capacity reached $20 \%$ for 8 wt. $\% \mathrm{C}_{16} \mathrm{OH}+\mathrm{C}_{20} \mathrm{OH}$-in-water emulsion with $\Delta T=10 \mathrm{~K}$. However, this value 
reduced to $11 \%$ for $\Delta T=15 \mathrm{~K}$. This evidences the importance of reducing the subcooling of dispersed droplets, since a $\Delta T=$ subcooling would be the minimum temperature interval that emulsions need to cover so that the PCM drops reversely undergo solid-liquid phase transition.

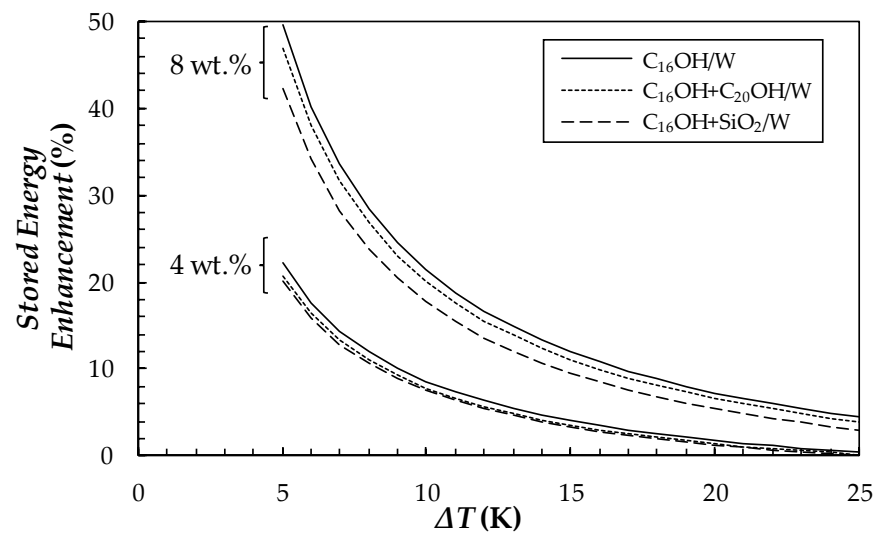

Figure 4. Enhancements in the stored thermal energy vs. temperature interval covered by nanoemulsion, $\Delta T$.

\subsection{Dynamic Viscosities}

The shear rate, $\dot{\gamma}$, and dependence of the dynamic viscosity, $\mu$, were investigated for water; the phosphate buffer solution $(0.04 \mathrm{M})$; bulk cetyl alcohol (only in the liquid phase) and the three nanoemulsions sets $\left(\mathrm{C}_{16} \mathrm{OH} / \mathrm{W}, \mathrm{C}_{16} \mathrm{OH}+\mathrm{C}_{20} \mathrm{OH} / \mathrm{W}\right.$ and $\left.\mathrm{C}_{16} \mathrm{OH}+\mathrm{SiO}_{2} / \mathrm{W}\right)$ at $\dot{\gamma}$ of $1-100 \mathrm{~s}^{-1}$ and temperatures between 283.15 and $333.15 \mathrm{~K}$. Figure 5a shows the flow curves obtained for water, PBS and some representative PCMEs at 283.15 K (when dispersed particles are solid). The $\mu$ results measured for water exhibited maximum deviations lower than $4 \%$ with the previous literature [80]. Slight differences (lower than 3\%, within experimental uncertainty) were observed between the viscosities of the water and the phosphate buffer solution used as a continuous phase. A viscosity value of $8.19 \mathrm{mPa} \cdot \mathrm{s}$ was measured for cetyl alcohol at $333.15 \mathrm{~K}$, which agreed with data of $7.91 \mathrm{mPa} \cdot \mathrm{s}$ reported by Fu et al. [81]. Like the phosphate buffer solution and bulk cetyl alcohol, nanoemulsions containing 2-6 wt.\% loadings of the dispersed phase are mainly Newtonian within the investigated shear rate. However, a slight decrease in shear viscosity with a rising shear rate (so-called pseudoplastic or shear thinning behavior) was observed for the $8 \mathrm{wt} . \%$ emulsions (particularly in the case of the emulsion containing silica nanoparticles).

As expected, viscosity strongly rises with the content of the dispersed phase. As also presented in Figure 5b, those increases are higher when droplets are solid (182-214\% in the case of higher of $8 \mathrm{wt} . \%$ emulsions) rather than liquid (137-165\% for the same samples). This effect, more noticeable with rising content of the dispersed phase, was also observed for other paraffin-in-water emulsions [10]. Several elucidations have been postulated in the literature to justify this behavior. However, changes in the (non-)elastic nature of collisions among neighboring PCM droplets, seems the most likely [82].

The temperature evolution of dynamic viscosity is presented for $\mathrm{C}_{16} \mathrm{OH}+\mathrm{C}_{20} \mathrm{OH} / \mathrm{W}$ system in Figure 5c. The results obtained for the higher concentrations of the $\mathrm{C}_{16} \mathrm{OH}$ $+\mathrm{C}_{20} \mathrm{OH} / \mathrm{W}$ and $\mathrm{C}_{16} \mathrm{OH}+\mathrm{SiO}_{2} / \mathrm{W}$ sets (8 wt. $\%$ of dispersed phase) are also included for comparison in Figure $5 c$. The downwards trend of the $\mu(T)$ curves with increasing temperature can be modeled by the Vogel-Fulcher-Tamman-Hesse (VFT) equation [83-85]:

$$
\ln \mu(T)=\ln \mu_{0}+\frac{D \cdot T_{0}}{T-T_{0}}
$$

where $\mu_{0}, D$ and $T_{0}$ are the fitting coefficients. As gathered in Table 3 , the measured viscosities can be correlated with standard deviations ranging from 0.03 to $0.07 \mathrm{mPa} \cdot \mathrm{s}$ (absolute average deviations, $A A D s \%$, of $1.3-2.9 \%$ ). 


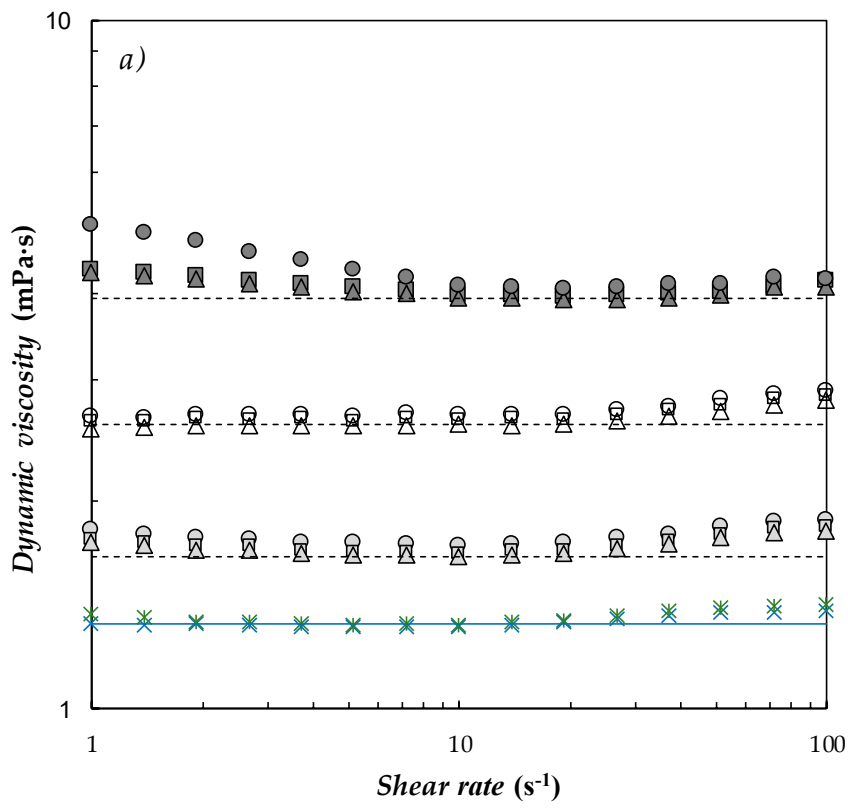

$\times$ Water

- Newtonian behaviour (water).

* Phosphate buffer solution, PBS, (0.04 M)

- $\mathrm{C}_{16} \mathrm{OH}(2$ wt.\%)/water

$\mathrm{C}_{16} \mathrm{OH}\left(1.8\right.$ wt.\%)+ $\mathrm{C}_{20} \mathrm{OH}(0.2$ wt.\%)/water

$\mathrm{C}_{16} \mathrm{OH}(1.96$ wt.\%)+SiO$(0.04$ wt.\%)/water

$\triangle \mathrm{C}_{16} \mathrm{OH}(6 \mathrm{wt} . \%) /$ water

$\square \quad \mathrm{C}_{16} \mathrm{OH}(5.4$ wt.\% $)+\mathrm{C}_{20} \mathrm{OH}(0.6$ wt.\%)/water

○ $\mathrm{C}_{16} \mathrm{OH}(5.88$ wt. $\%)+\mathrm{SiO}_{2}(0.12$ wt. $\%) /$ water

$\Delta \mathrm{C}_{16} \mathrm{OH}(8 \mathrm{wt} . \%) /$ water

- $\mathrm{C}_{16} \mathrm{OH}\left(7.2\right.$ wt.\%) $+\mathrm{C}_{20} \mathrm{OH}(0.8$ wt.\%)/water

- $\mathrm{C}_{16} \mathrm{OH}(7.84$ wt. $\%)+\mathrm{SiO}_{2}(0.16$ wt.\%)/water

- - Newtonian behaviour $\left(\mathrm{C}_{16} \mathrm{OH} /\right.$ water samples $)$

$\mathrm{C}_{16} \mathrm{OH} /$ water

$\mathrm{C}_{16} \mathrm{OH}+\mathrm{C}_{20} \mathrm{OH} /$ water $\left(\mathrm{C}_{16} \mathrm{OH}: \mathrm{C}_{20} \mathrm{OH}=9: 1\right)$

$\mathrm{C}_{16} \mathrm{OH}+\mathrm{SiO}_{2} /$ water $\left(\mathrm{C}_{16} \mathrm{OH}: \mathrm{SiO}_{2}=49: 1\right)$

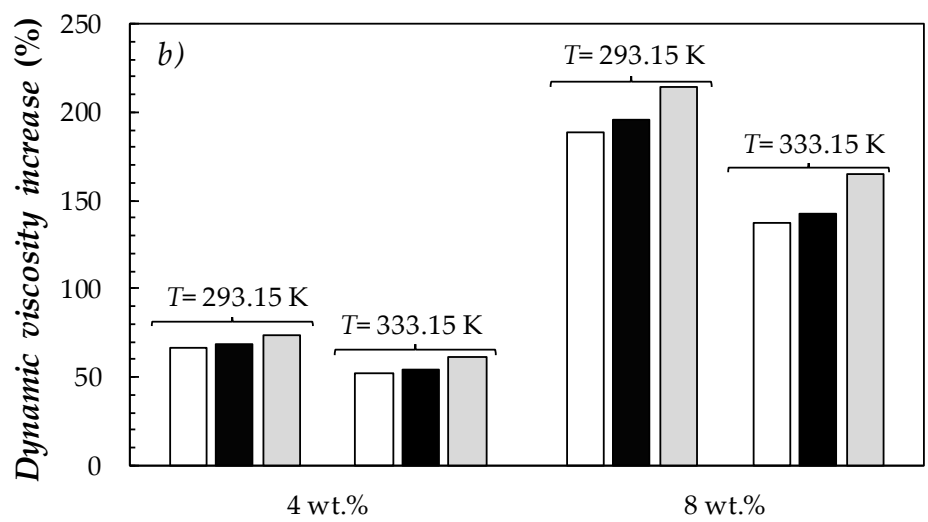

Dispersed phase content $(\mathrm{PCM}+\mathrm{NA})$

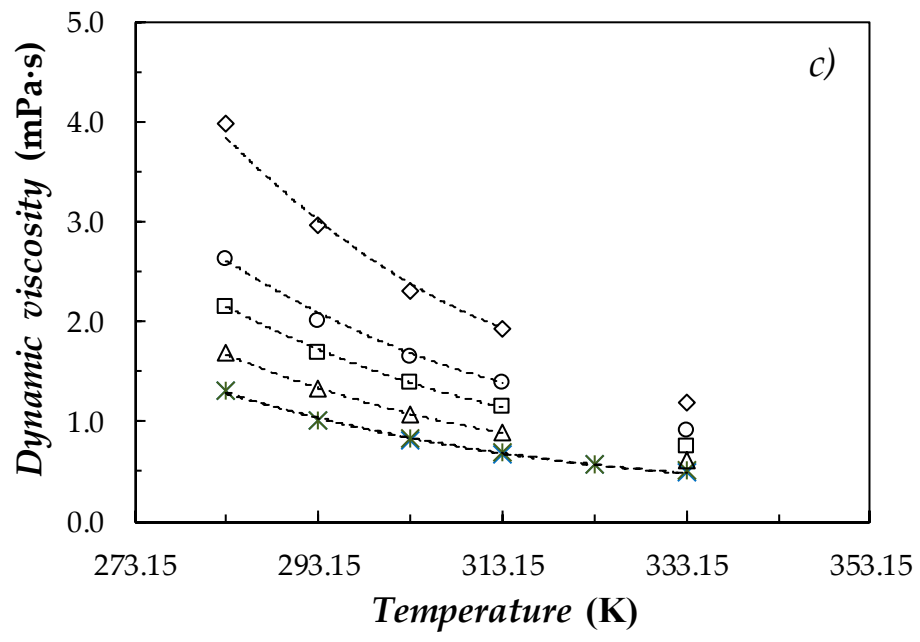
$\times$ Water
* Phosphate buffer solution, PBS, (0.04 M)
$\triangle \mathrm{C}_{16} \mathrm{OH}(1.8$ wt. $\%)+\mathrm{C}_{20} \mathrm{OH}(0.2$ wt.\%)/water
$\square \quad \mathrm{C}_{16} \mathrm{OH}\left(3.6\right.$ wt.\%)+C $\mathrm{C}_{20} \mathrm{OH}(0.4$ wt.\%)/water
○ $\mathrm{C}_{16} \mathrm{OH}(5.4$ wt. $\%)+\mathrm{C}_{20} \mathrm{OH}(0.6$ wt. $\%) /$ water
$\diamond \mathrm{C}_{16} \mathrm{OH}(7.2$ wt. $\%)+\mathrm{C}_{20} \mathrm{OH}(0.8$ wt. $\%) /$ water
- VFT equation, Equation (3)

Figure 5. (a) Shear rate-shear viscosity flow curves obtained for water, PBS and some nanoemulsions at $283.15 \mathrm{~K}$; (b) increases in the viscosity (regarding water) obtained at $293.15 \mathrm{~K}$ (solid dispersed droplets) and $333.15 \mathrm{~K}$ (liquid dispersed droplets) for emulsions loaded with 4 and $8 \mathrm{wt} \%$ of the dispersed phase and (c) temperature dependence of the viscosity for the $\mathrm{C}_{16} \mathrm{OH}+\mathrm{C}_{20} \mathrm{OH} / \mathrm{W}$ system. Temperature uncertainty $U(T): 0.1 \mathrm{~K}$. Viscosity uncertainty $U(\mu): 5 \%$. 
Table 3. Fitting parameters $\left(\eta_{0}, D\right.$ and $\left.T_{0}\right)$; standard deviations $(s)$ and absolute average deviations $(A A D \%)$ obtained from the Vogel-Fulcher-Tamman-Hesse model, Equation (3), when modeling the temperature dependence of the shear viscosities obtained for some representative samples at $\sim 100 \mathrm{~s}^{-1}$.

\begin{tabular}{|c|c|c|c|c|c|c|c|}
\hline \multirow[b]{2}{*}{ Parameter } & \multirow{2}{*}{$\begin{array}{l}\text { Phosphate Buffer Solution, } \\
\text { PBS, (0.04 M) }\end{array}$} & \multicolumn{6}{|c|}{ Water-Based Emulsions } \\
\hline & & $\begin{array}{l}\mathrm{C}_{16} \mathrm{OH} \\
(2 \text { wt. } \%)\end{array}$ & $\begin{array}{l}\mathrm{C}_{16} \mathrm{OH} \\
(4 \mathrm{wt} . \%)\end{array}$ & $\begin{array}{l}\mathrm{C}_{16} \mathrm{OH} \\
(6 \mathrm{wt} . \%)\end{array}$ & $\begin{array}{l}\mathrm{C}_{16} \mathrm{OH} \\
(8 \mathrm{wt} . \%)\end{array}$ & $\begin{array}{l}\mathrm{C}_{16} \mathrm{OH}(7.8 \mathrm{wt} . \%)+ \\
\mathrm{C}_{20} \mathrm{OH}(0.2 \mathrm{wt} . \%)\end{array}$ & $\begin{array}{l}\mathrm{C}_{16} \mathrm{OH}(7.84 \text { wt. } \%)+ \\
\mathrm{SiO}_{2}(0.16 \text { wt. } \%)\end{array}$ \\
\hline$\eta_{0} / \mathrm{mPa} \cdot \mathrm{s}$ & 0.00162 & 0.00213 & 0.00281 & 0.00328 & 0.00473 & 0.00480 & 0.00542 \\
\hline$D$ & 75.182 & 75.208 & 75.257 & 75.280 & 75.297 & 75.247 & 75.245 \\
\hline$T_{0} / \mathrm{K}$ & 23.175 & 23.167 & 23.152 & 23.145 & 23.132 & 23.155 & 23.156 \\
\hline $\mathrm{s} / \mathrm{mPa} \cdot \mathrm{s}$ & 0.037 & 0.045 & 0.066 & 0.061 & 0.046 & 0.048 & 0.047 \\
\hline$A A D \%$ & $1.4 \%$ & $1.9 \%$ & $2.9 \%$ & $2.5 \%$ & $1.1 \%$ & $1.7 \%$ & $1.8 \%$ \\
\hline
\end{tabular}

\subsection{Thermal Conductivity}

Experimental thermal conductivities, $\lambda$, for water, the phosphate buffer solution (PBS) used as the continuous phase and several cetyl alcohol-in-water nanoemulsions are plotted in Figure 6a. The measured $\lambda$ value for bulk cetyl alcohol in the liquid phase was $0.133 \mathrm{~W} \cdot \mathrm{m}^{-1} \cdot \mathrm{K}^{-1}$ (at $333 \mathrm{~K}$ ), which is in agreement (within $1.5 \%$ ) with the data of $0.131 \mathrm{~W} \cdot \mathrm{m}^{-1} \cdot \mathrm{K}^{-1}$ reported by Huang et al. [86]. In the studied temperature range, the results obtained for water showed an absolute average deviation of $2.5 \%$ and a maximum deviation of $3.9 \%$ with the values recommended by REFPROP [80].
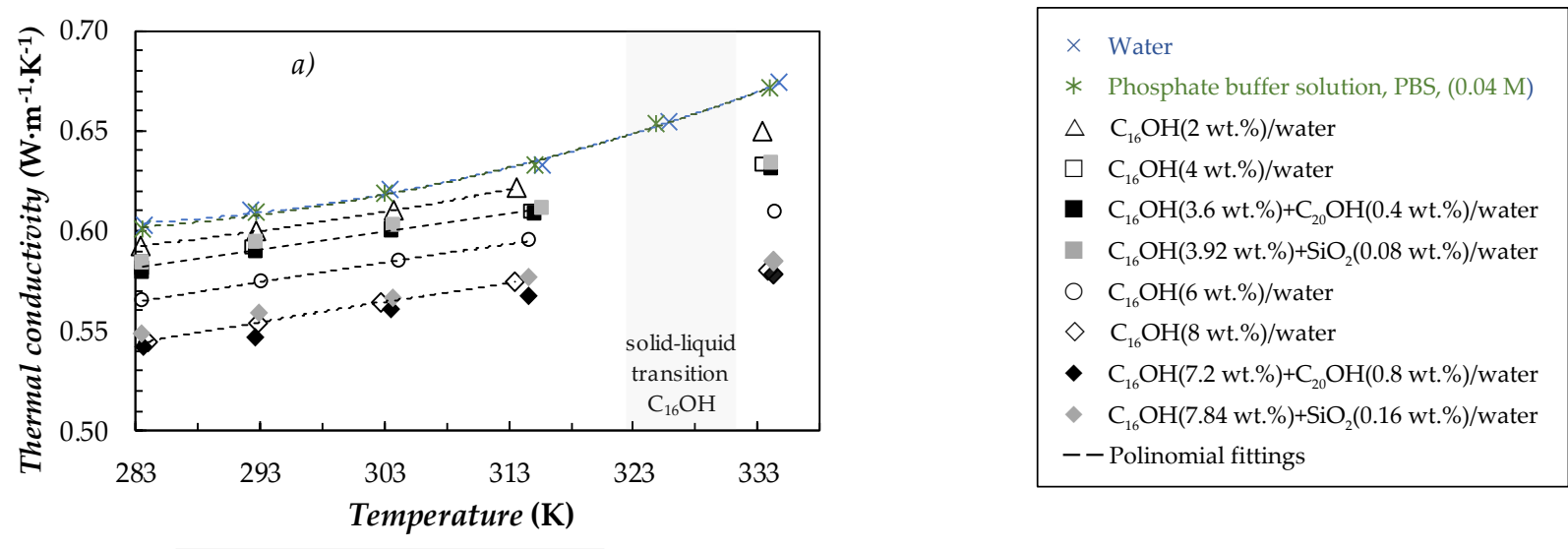

\begin{tabular}{|c|c|}
\hline & $\underline{T=293 \mathrm{~K} \text { (solid droplets) }}$ \\
\hline $\mathbf{\Delta}$ & $\mathrm{C}_{16} \mathrm{OH} /$ water \\
\hline & $\mathrm{C}_{16} \mathrm{OH}+\mathrm{C}_{20} \mathrm{OH} /$ water \\
\hline & $\mathrm{C}_{16} \mathrm{OH}+\mathrm{SiO}_{2} /$ water \\
\hline & - Maxwell model, Equation (4) \\
\hline & $\begin{array}{l}\text { Area defined by H-S model, } \\
\text { Equation (5-6). }\end{array}$ \\
\hline & $T=333 \mathrm{~K}$ (liquid droplets) \\
\hline$\triangle$ & $\mathrm{C}_{16} \mathrm{OH} /$ water \\
\hline$\square$ & $\mathrm{C}_{16} \mathrm{OH}+\mathrm{C}_{20} \mathrm{OH} /$ water \\
\hline ○ & $\mathrm{C}_{16} \mathrm{OH}+\mathrm{SiO}_{2} /$ water \\
\hline$-\cdots$ & Maxwell model, Equation (4) \\
\hline$\nabla$ & $\begin{array}{l}\text { Area defined by H-S model, } \\
\text { Equation (5-6). }\end{array}$ \\
\hline
\end{tabular}

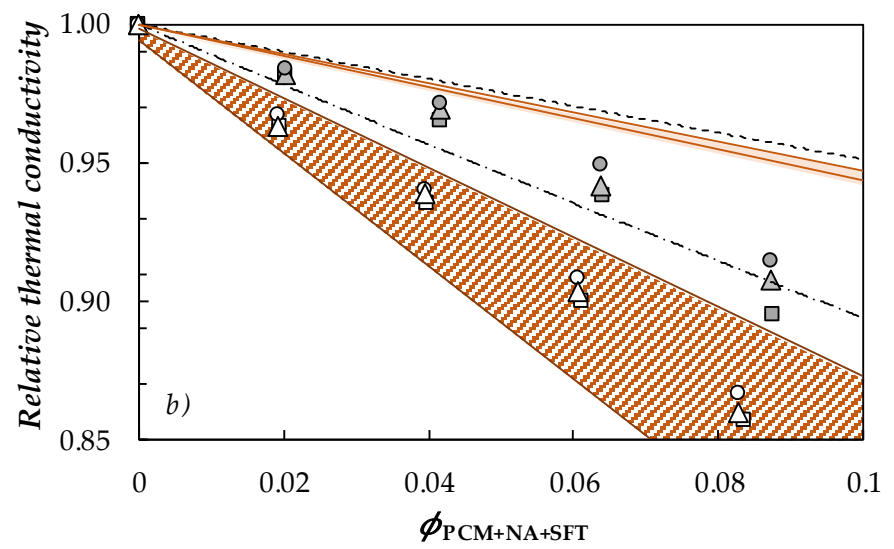

Figure 6. (a) Thermal conductivity vs. temperature for some representative emulsions and (b) volume fraction, $\phi_{\mathrm{PCM}+\mathrm{NA}+\mathrm{SFT}}$, dependence of the relative thermal conductivity (defined as $\lambda_{\mathrm{PCME}} / \lambda_{\mathrm{PBS}}$ ). Temperature uncertainty $U(T): 0.1 \mathrm{~K}$. Thermal conductivity uncertainty $U(\lambda): 5 \%$. 
Given the lower thermal conductivity of fatty alcohols (in comparison with water), $\lambda$ reduces with the increasing concentration of the dispersed phase. The diminutions in thermal conductivity are larger when dispersed droplets are liquid (13.3-14.3\% for the emulsions containing $8 \mathrm{wt} . \%$ of the dispersed phase) than when they are solid $(8.5-10.5 \%$ at the same concentration). These results agree with the fact that the thermal conductivity of cetyl alcohol is lower in the liquid than in the solid phase $\left(0.35-0.36 \mathrm{~W} \cdot \mathrm{m}^{-1} \cdot \mathrm{K}^{-1}[70,87]\right)$. Even if the variations are within the experimental uncertainty, a comparison between $\lambda$ values of three different studied PCME sets mainly shows: $\mathrm{C}_{16} \mathrm{OH}+\mathrm{SiO}_{2} / \mathrm{W}>\mathrm{C}_{16} \mathrm{OH} / \mathrm{W}$ $>\mathrm{C}_{16} \mathrm{OH}+\mathrm{C}_{20} \mathrm{OH} / \mathrm{W}$.

Maxwell [88] proposed a semiempirical equation to predict the thermal conductivity of low-concentrated dispersions of noninteracting spheres:

$$
\lambda_{\mathrm{PCME}} / \lambda_{\mathrm{PBS}}=\frac{2 \cdot \lambda_{\mathrm{PBS}}+\lambda_{\mathrm{PCM}+\mathrm{NA}+\mathrm{SFT}}+2 \cdot \phi_{\mathrm{PCM}+\mathrm{NA}+\mathrm{SFT}} \cdot\left(\lambda_{\mathrm{PCM}+\mathrm{NA}+\mathrm{SFT}}-\lambda_{\mathrm{PBS}}\right)}{2 \cdot \lambda_{\mathrm{PBS}}+\lambda_{\mathrm{PCM}+\mathrm{NA}+\mathrm{SFT}}-\phi_{\mathrm{PCM}+\mathrm{NA}+\mathrm{SFT}} \cdot\left(\lambda_{\mathrm{PCM}+\mathrm{NA}+\mathrm{SFT}}-\lambda_{\mathrm{PBS}}\right)}
$$

In the case of macroscopically homogeneous multiphase systems, Hashin and Shtrikman $(\mathrm{H}-\mathrm{S})$ [89] also derived the two following expressions for the lower and upper bounds of effective thermal conductivity:

$$
\begin{aligned}
& \lambda_{\mathrm{PCME}} / \lambda_{\mathrm{PBS}}=\left[1+\frac{2 \cdot \phi_{\mathrm{PCM}+\mathrm{NA}+\mathrm{SFT}} \cdot\left(\lambda_{\mathrm{PCM}+\mathrm{NA}+\mathrm{SFT}} / \lambda_{\mathrm{PBS}}-1\right)}{1+\lambda_{\mathrm{PCM}+\mathrm{NA}+\mathrm{SFT}} / \lambda_{\mathrm{PBS}}-\phi_{\mathrm{PCM}+\mathrm{NA}+\mathrm{SFT}} \cdot\left(\lambda_{\mathrm{PCM}+\mathrm{NA}+\mathrm{SFT}} / \lambda_{\mathrm{PBS}}-1\right)}\right] \\
& \lambda_{\mathrm{PCME}} / \lambda_{\mathrm{PBS}}=\lambda_{\mathrm{PCM}+\mathrm{NA}+\mathrm{SFT}} / \lambda_{\mathrm{PBS}} \cdot\left[1-\frac{2 \cdot\left(1-\phi_{\mathrm{PCM}+\mathrm{NA}+\mathrm{SFT}}\right) \cdot\left(\lambda_{\mathrm{PCM}+\mathrm{NA}+\mathrm{SFT}} / \lambda_{\mathrm{PBS}}-1\right)}{2 \cdot \lambda_{\mathrm{PCM}+\mathrm{NA}+\mathrm{SFT}} / \lambda_{\mathrm{PBS}}-\phi_{\mathrm{PCM}+\mathrm{NA}+\mathrm{SFT}} \cdot\left(\lambda_{\mathrm{PCM}+\mathrm{NA}+\mathrm{SFT}} / \lambda_{\mathrm{PBS}}-1\right)}\right]
\end{aligned}
$$

In our work, the thermal conductivity of dispersed droplets (phase change material + nucleating agent + surfactant mixture, $\lambda_{\mathrm{PCM}+\mathrm{NA}+\mathrm{SFT}}$ ) was assumed equal to that of cetyl alcohol. Figure $6 \mathrm{~b}$ presents the relationship between the $\lambda_{\mathrm{PCME}} / \lambda_{\mathrm{PBS}}$ ratio and volume fraction of the dispersed phase. As can be observed, our experimental thermal conductivities were lower than predicted by the Maxwell model [88]. The deviations reached 5\% in the case of emulsions prepared at the highest concentrations of the dispersed phase. A similar result was also reported by Kawanami et al. [90] when investigating $n$-octadecane-in-water emulsions. When compared with the Hashin and Shtrikman [89] model, effective experimental thermal conductivities at $333 \mathrm{~K}$ (liquid droplets) fall within the upper and lower bounds predicted by Equations (5) and (6). However, when dispersed droplets are solid, the experimental $\lambda_{\mathrm{PCME}} / \lambda_{\mathrm{PBS}}$ ratios are lower than calculated by the H-S [89] equations.

\subsection{Density}

Density, $\rho$, was investigated for water and the phosphate buffer solution (PBS $0.04 \mathrm{M}$ ), as well as $\mathrm{C}_{16} \mathrm{OH} / \mathrm{W}$ and $\mathrm{C}_{16} \mathrm{OH}+\mathrm{C}_{20} \mathrm{OH} / \mathrm{W}$ emulsions. Figure 7a shows the temperature evolution of density for the $\mathrm{C}_{16} \mathrm{OH} / \mathrm{W}$ samples prepared at different concentrations of fatty alcohol. The $\mathrm{C}_{16} \mathrm{OH}+\mathrm{C}_{20} \mathrm{OH} / \mathrm{W}$ emulsion prepared with the highest content of the dispersed phase is also shown for comparison. Slightly higher values $(0.2 \%)$ were observed for the phosphate buffer solution in comparison to water. Nanoemulsion densities reduced with the rising content of the dispersed phase. At the $8 \mathrm{wt}$ \% concentration, diminutions reached $1.2 \%$ and $1.8 \%$ when the $\mathrm{C}_{16} \mathrm{OH}$ droplets were solid and liquid, respectively. $\mathrm{C}_{16} \mathrm{OH}+\mathrm{C}_{20} \mathrm{OH} / \mathrm{W}$ densities are slightly higher than $\mathrm{C}_{16} \mathrm{OH} / \mathrm{W}$, but the deviations are $<0.07 \%$ (almost the experimental uncertainty). The experimental results for the $\mathrm{C}_{16} \mathrm{OH} / \mathrm{W}$ system at temperatures higher than $328.15 \mathrm{~K}$ (when cetyl alcohol is liquid) exhibited deviations lower than $0.4 \%$ with the values provided by means of the following weighted average equation based on the mixing theory:

$$
\frac{1}{\rho_{\mathrm{PCME}}}=\frac{\varphi_{\mathrm{PCM}}}{\rho_{\mathrm{PCM}}}+\frac{\varphi_{\mathrm{SFT}}}{\rho_{\mathrm{SFT}}}+\frac{1-\varphi_{\mathrm{PCM}}-\varphi_{\mathrm{SFT}}}{\rho_{\mathrm{PBS}}}
$$




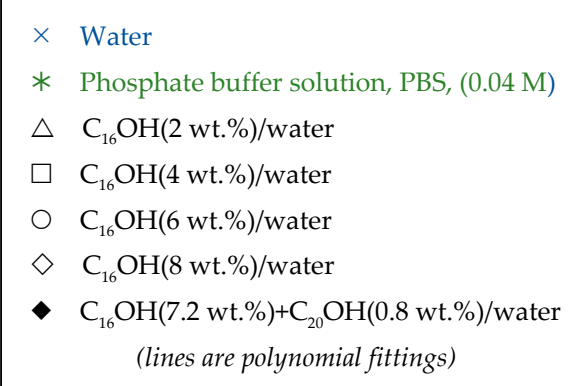

$\times$ Water

$\diamond \mathrm{C}_{16} \mathrm{OH}(8 \mathrm{wt} . \%) /$ water

(ines are polynomial fittings
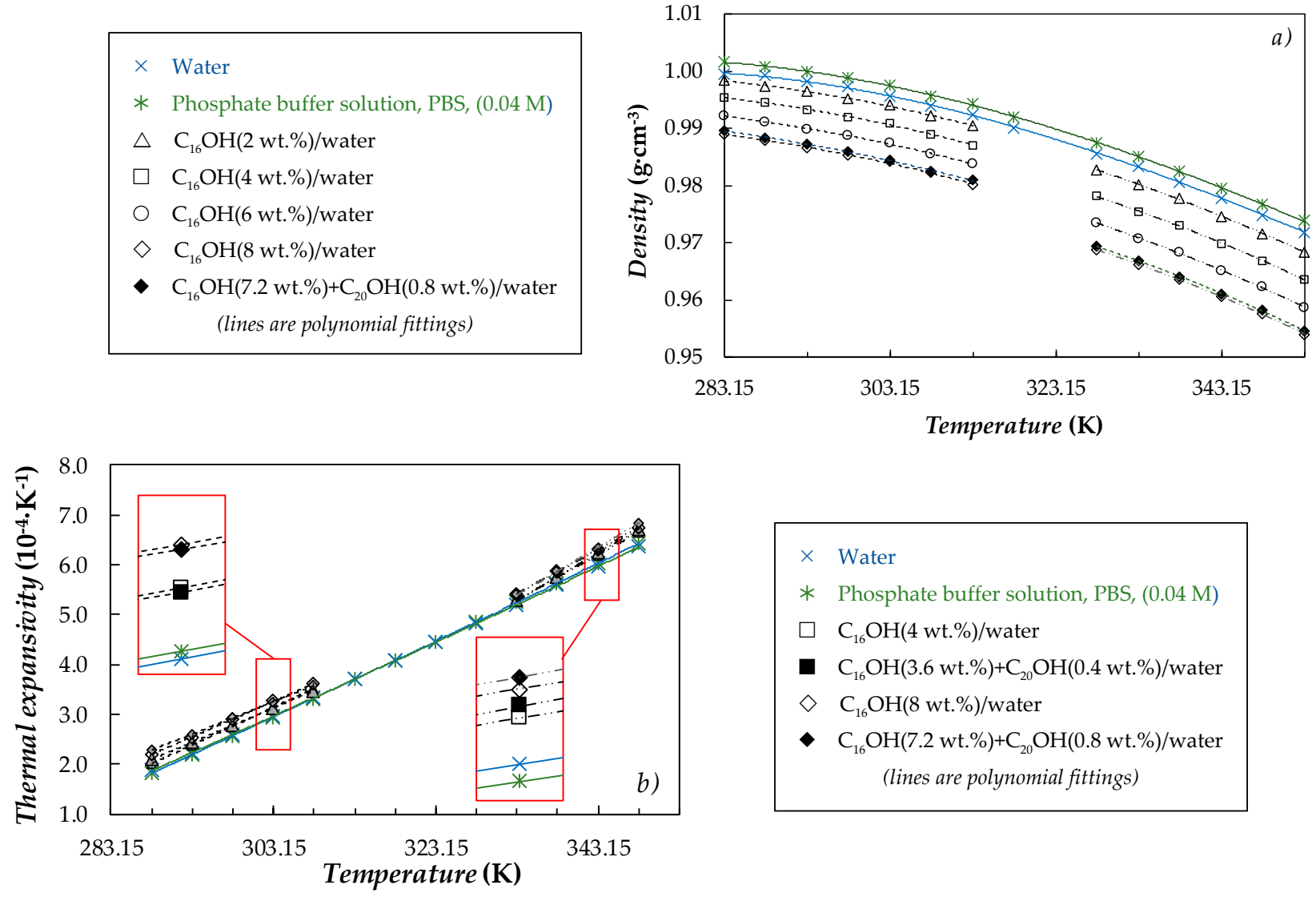

$\begin{array}{cl}\times & \text { Water } \\ * & \text { Phosphate buffer solution, } \mathrm{PBS},(0.04 \mathrm{M}) \\ \square & \mathrm{C}_{16} \mathrm{OH}(4 \text { wt. } \%) / \text { water } \\ \square & \mathrm{C}_{16} \mathrm{OH}(3.6 \text { wt. } \%)+\mathrm{C}_{20} \mathrm{OH}(0.4 \text { wt. } \%) / \text { water } \\ \diamond & \mathrm{C}_{16} \mathrm{OH}(8 \text { wt. } \%) / \text { water } \\ \bullet & \mathrm{C}_{16} \mathrm{OH}(7.2 \text { wt. } \%)+\mathrm{C}_{20} \mathrm{OH}(0.8 \text { wt. } \%) / \text { water } \\ & \quad \text { (lines are polynomial fittings) }\end{array}$

Figure 7. Temperature dependence of the (a) density and (b) isobaric thermal expansivity for water, phosphate buffer solutions and $\mathrm{C}_{16} \mathrm{OH}$-in-water or/and $\mathrm{C}_{16} \mathrm{OH}+\mathrm{C}_{20} \mathrm{OH}$-in-water PCMEs. Temperature uncertainty $U(T): 0.1 \mathrm{~K}$. Density uncertainty $U(\rho): 0.05 \%$. Thermal expansivity uncertainty $U\left(\alpha_{\mathrm{p}}\right): 4 \%$.

A noticeable change in $\rho$ can be appreciated for the emulsion systems at temperatures around the solid-liquid phase change of cetyl alcohol. Thus, in the temperature range 313.15-328.15 K, water-based emulsions containing 8 wt. $\%$ of $\mathrm{C}_{16} \mathrm{OH}$ or $\mathrm{C}_{16} \mathrm{OH}+\mathrm{C}_{20} \mathrm{OH}$ exhibit changes in the density of $1.2 \%$, which is almost double the value of water $(0.7 \%)$ in that same temperature interval. $\rho$ modifications with the temperature were further analyzed by means of the isobaric thermal expansivity, $\alpha_{\mathrm{p}}$. This property can be calculated from the numerical differentiation of density-temperature curves using the following expression:

$$
\alpha_{p}=-(1 / \rho) \cdot(\partial \rho / \partial T)_{p}
$$

A function of temperature by a two second-order polynomial, i.e., $\rho=A_{2} \cdot T^{2}+A_{1} \cdot T+A_{0}$, was fitted to the experimental densities. In the case of nanoemulsions, two polynomial fittings were used: one for $283.15 \mathrm{~K} \leq T \leq 313.15 \mathrm{~K}$ (fatty alcohol droplets are solid) and the other for $328.15 \mathrm{~K} \leq T \leq 353.15 \mathrm{~K}$ (liquid droplets). The $A_{i}$ fitting coefficients are gathered in Table 4. Figure $7 \mathrm{~b}$ compares the $\alpha_{p}$ values of water and the buffer solution with those of four representative $\mathrm{C}_{16} \mathrm{OH} / \mathrm{W}$ and $\mathrm{C}_{16} \mathrm{OH}+\mathrm{C}_{20} \mathrm{OH} / \mathrm{W}$ emulsions. As can be observed, the isobaric thermal expansivity increases with the content of dispersed fatty alcohol, which agrees with the fact that cetyl alcohol has a higher expansivity $\left(\alpha_{p}=7-8 \cdot 10^{-4} \mathrm{~K}^{-1}\right.$ at $343 \mathrm{~K}[81,91])$ than water. 
Table 4. The $A_{i}$ coefficients and percentage absolute average deviations, $A A D \%$, obtained from second-order polynomial fittings of the density results.

\begin{tabular}{|c|c|c|c|c|c|c|}
\hline \multirow[b]{2}{*}{ Parameter } & \multirow{2}{*}{$\begin{array}{l}\text { Phosphate Buffer Solution, } \\
\text { PBS, (0.04 M) }\end{array}$} & \multicolumn{5}{|c|}{ Water-Based Nanoemulsions } \\
\hline & & $\begin{array}{l}\mathrm{C}_{16} \mathrm{OH} \\
(2 \mathrm{wt} . \%)\end{array}$ & $\begin{array}{l}\mathrm{C}_{16} \mathrm{OH} \\
(4 \text { wt. } \%)\end{array}$ & $\begin{array}{l}\mathrm{C}_{16} \mathrm{OH} \\
(6 \text { wt. } \%)\end{array}$ & $\begin{array}{l}\mathrm{C}_{16} \mathrm{OH} \\
(8 \mathrm{wt} . \%)\end{array}$ & $\begin{array}{l}\mathrm{C}_{16} \mathrm{OH}(7.8 \text { wt. } \%)+ \\
\mathrm{C}_{20} \mathrm{OH}(0.2 \text { wt. } \%)\end{array}$ \\
\hline \multicolumn{2}{|c|}{$283.15 \mathrm{~K} \leq T \leq 353.15 \mathrm{~K}$} & \multicolumn{5}{|c|}{$283.15 \mathrm{~K} \leq T \leq 313.15 \mathrm{~K}$ (fatty alcohol droplets are solid) } \\
\hline$A_{0} / \mathrm{g} \cdot \mathrm{cm}^{-3}$ & $0.75 \overline{4} 9$ & 0.7301 & 0.7437 & 0.7750 & 0.7618 & 0.7925 \\
\hline $10^{3} \cdot A_{1} / \mathrm{g} \cdot \mathrm{cm}^{-3} \cdot \mathrm{K}^{-1}$ & 1.895 & 2.039 & 1.941 & 1.711 & 1.786 & 1.586 \\
\hline$-10^{6} \cdot A_{2} / \mathrm{g} \cdot \mathrm{cm}^{-3} \cdot \mathrm{K}^{-2}$ & 3.614 & 3.857 & 3.714 & 3.333 & 3.476 & 3.143 \\
\hline \multirow[t]{2}{*}{$A A D \%$} & $0.12 \%$ & $0.14 \%$ & $0.11 \%$ & $0.11 \%$ & $0.13 \%$ & $0.12 \%$ \\
\hline & & \multicolumn{5}{|c|}{$328.15 \mathrm{~K} \leq T \leq 353.15 \mathrm{~K}$ (fatty alcohol droplets are liquid) } \\
\hline$A_{0} / \mathrm{g} \cdot \mathrm{cm}^{-3}$ & & 0.6829 & 0.6802 & 0.7437 & 0.6891 & 0.6493 \\
\hline $10^{3} \cdot A_{1} / \mathrm{g} \cdot \mathrm{cm}^{-3} \cdot \mathrm{K}^{-1}$ & & 2.296 & 2.291 & 1.896 & 2.188 & 2.429 \\
\hline$-10^{6} \cdot A_{2} / \mathrm{g} \cdot \mathrm{cm}^{-3} \cdot \mathrm{K}^{-2}$ & & 4.214 & 4.214 & 3.643 & 4.071 & 4.429 \\
\hline$A A D \%$ & & $0.11 \%$ & $0.10 \%$ & $0.11 \%$ & $0.11 \%$ & $0.11 \%$ \\
\hline
\end{tabular}

\section{Conclusions}

Cetyl alcohol-in-water nanoemulsions containing 2, 4, 6 and $8 \mathrm{wt} . \%$ of the dispersed phase were prepared following a solvent-assisted method. The sample composition was optimized in order to obtain PCMs with small droplets (in the range of 100-220 nm), good fluidity and stability through time and after the freeze-thaw cycles. Phase change analyses showed that nanoemulsions containing only cetyl alcohol as the dispersed phase exhibited subcooling effects of up to $10 \mathrm{~K}$. Eicosyl and hydrophobic silica nanoparticles were tested as nucleating agents, and the former proved to be a good option to trigger heterogeneous nucleation and reduce the subcooling of dispersed droplets to a few degrees. The 2-6 wt.\% samples exhibited a desirable Newtonian viscosity, while the $8 \mathrm{wt} . \%$ dispersions presented a slight shear thinning behavior (more noticeable in the case of samples containing silica nanoparticles as the nucleating agent). Even if the PCMEs had thermal conductivities much larger than bulk cetyl alcohol (at least $60 \%$ better when dispersed droplets are solid), this property reduced with the increasing content of fatty alcohol. Volumetric studies showed a change in the density of $1.2 \%$ (which was almost double the value of water) in the temperature range in which fatty alcohol droplets undergo solid-liquid phase change. The dispersion of cetyl alcohol droplets proved to increase the thermal capacity of water. Thus, PCMEs with $8 \mathrm{wt} . \%$ of the dispersed phase showed an energy storage capacity $20 \%$ higher (considering an operational temperature interval of $10 \mathrm{~K}$ around the solid-liquid transition of cetyl alcohol).

Author Contributions: Conceptualization, D.C., S.L.-B. and L.F.; methodology, F.A., S.B. and S.L.-B.; formal analysis, F.A., L.L., M.M.P. and L.F.; investigation, D.C. and C.H.-M.; writing-original draft preparation, D.C., C.H.-M. and L.F. and writing-review and editing, S.L.-B., S.B., L.L. and M.M.P. All authors have read and agreed to the published version of the manuscript.

Funding: This work is a contribution to the European Cooperation in Science and Technology (COST) CIG Action-NANOCONVEX. The authors would like to acknowledge KET4F-Gas project, SOE2/P1/P0823, co-funded by the Interreg Sudoe Program through the European Regional Development Fund (ERDF), as well as the ENE2017-86425-C2-1-R and PID2020-112846RB-C21 projects supported by the "Ministerio de Ciencia e Innovación" (Spain) and ERDF. D. Cabaleiro acknowledges a postdoctoral fellowship from Xunta de Galicia (Spain) and a Juan de la Cierva fellowship from "Ministerio de Ciencia e Innovación" (Spain). L. Fedele acknowledges Bando STM (Short Term Mobility) 2021 from CNR (Consiglio Nazionale delle Ricerche, Italy).

Institutional Review Board Statement: Not applicable.

Conflicts of Interest: The authors declare no conflict of interest. 


\section{Nomenclature}

\begin{tabular}{|c|c|}
\hline$A A D \%$ & percentage absolute average deviations; \\
\hline$A_{i}$ & second-order polynomial coefficients \\
\hline$\alpha_{p}$ & thermal expansivity $\left[\mathrm{K}^{-1}\right]$ \\
\hline$\beta$ & heating / cooling scanning rate $\left[\mathrm{K} \cdot \mathrm{min}^{-1}\right]$ \\
\hline$c_{p}$ & isobaric heat capacity $\left[\mathrm{J} \cdot \mathrm{g}^{-1} \cdot \mathrm{g}^{-1}\right]$ \\
\hline $\mathrm{C}_{16} \mathrm{OH}$ & cetyl alcohol or 1-hexadecanol \\
\hline $\mathrm{C}_{20} \mathrm{OH}$ & eicosyl alcohol or 1-eicosanol \\
\hline CTAC & cetyltrimethylammonium chloride \\
\hline DLS & dynamic light scattering \\
\hline DSC & differential scanning calorimetry \\
\hline$\Delta h_{\text {latent }}$ & latent heat $\left[\mathrm{J} \cdot \mathrm{g}^{-1}\right]$ \\
\hline$\Delta T$ & temperature difference covered by the sample $[\mathrm{K}]$ \\
\hline$\varphi$ & volume fraction; \\
\hline$\dot{\gamma}$ & shear rate $\left[\mathrm{s}^{-1}\right]$; \\
\hline NA & nucleating agent \\
\hline $\mathrm{N}_{2}$ & nitrogen \\
\hline HAVC & heating, ventilation and air conditioning \\
\hline PBS & phosphate buffer solution \\
\hline PCM & phase change material \\
\hline PCME & phase change material emulsion \\
\hline$p d i$ & polydispersity index \\
\hline$\rho$ & density $\left[\mathrm{g} \cdot \mathrm{cm}^{-3}\right]$ \\
\hline$S$ & standard deviation \\
\hline SDBS & sodium dodecylbenzenesulfonate \\
\hline SDS & sodium dodecyl sulfate \\
\hline SFT & surfactant \\
\hline $\mathrm{SiO}_{2}$ & silica nanoparticles \\
\hline$T$ & temperature $[\mathrm{K}]$ \\
\hline TES & thermal energy storage \\
\hline$\lambda$ & thermal conductivity $\left[\mathrm{W} \cdot \mathrm{m}^{-1} \cdot \mathrm{K}^{-1}\right]$ \\
\hline$\mu$ & shear dynamic viscosity $[\mathrm{mPa} \cdot \mathrm{s}]$ \\
\hline$\mu_{\mathrm{r}}=\mu_{P C M} / \mu_{\text {water }+S D S}$ & relative viscosity of sample to corresponding water + SDS mixture \\
\hline VFT & Vogel-Fulcher-Tamman-Hesse $\left(\mu_{0}, \mathrm{D}\right.$ and $\mathrm{T}_{0}$ : VFT fitting coefficients) \\
\hline W & water; \\
\hline wt. $\%$ & mass concentration \\
\hline \multicolumn{2}{|l|}{ Subscripts } \\
\hline CF & carrier fluid \\
\hline latent & latent \\
\hline melt. & melting \\
\hline$p$ & peak temperature \\
\hline PCM & phase change materials \\
\hline PCME & phase change material emulsion \\
\hline sol. & solidification. \\
\hline
\end{tabular}

\section{References}

1. Bretschger, L.; Pittel, K. Twenty key challenges in environmental and resource economics. Environ. Resour. Econ. 2020, 77, 725-750. [CrossRef]

2. Colmenar-Santos, A.; Muñoz-Gómez, A.-M.; López-Rey, Á.; Rosales-Asensio, E. Strategy to support renewable energy sources in Europe. In Design, Analysis, and Applications of Renewable Energy Systems. Advances in Nonlinear Dynamics and Chaos (ANDC); Academic Press: Cambridge, MA, USA, 2021; pp. 103-120. [CrossRef]

3. Nieto, J.; Carpintero, Ó.; Lobejón, L.F.; Miguel, L.J. An ecological macroeconomics model: The energy transition in the EU. Energy Policy 2020, 145, 111726. [CrossRef]

4. Saha, S.; Ruslan, A.R.M.; Monjur Morshed, A.K.M.; Hasanuzzaman, M. Global prospects and challenges of latent heat thermal energy storage: A review. Clean Technol. Environ. Policy 2021, 23, 531-559. [CrossRef]

5. Zhang, H.; Baeyens, J.; Cáceres, G.; Degrève, J.; Lv, Y. Thermal energy storage: Recent developments and practical aspects. Prog. Energy Combust. Sci. 2016, 53, 1-40. [CrossRef] 
6. Pielichowska, K.; Pielichowski, K. Phase change materials for thermal energy storage. Prog. Mater. Sci. 2014, 65, 67-123. [CrossRef]

7. O'Neill, P.; Fischer, L.; Revellin, R.; Bonjour, J. Phase change dispersions: A literature review on their thermo-rheological performance for cooling applications. Appl. Therm. Eng. 2021, 192, 116920. [CrossRef]

8. Cabaleiro, D.; Hamze, S.; Agresti, F.; Estellé, P.; Barison, S.; Fedele, L.; Bobbo, S. Dynamic viscosity, surface tension and wetting behavior studies of paraffin-in-water nano-emulsions. Energies 2019, 12, 3334. [CrossRef]

9. Morimoto, T.; Suzuki, K.; Kumano, H. Heat transfer characteristics of phase change emulsions with solidification of phase change material particles in a circular tube. Int. J. Refrig. 2020, 114, 1-9. [CrossRef]

10. Mikkola, V.; Puupponen, S.; Saari, K.; Ala-Nissila, T.; Seppälä, A. Thermal properties and convective heat transfer of phase changing paraffin nanofluids. Int. J. Therm. Sci. 2017, 117, 163-171. [CrossRef]

11. Morimoto, T.; Kawana, Y.; Saegusa, K.; Kumano, H. Supercooling characteristics of phase change material particles within phase change emulsions. Int. J. Refrig. 2019, 99, 1-7. [CrossRef]

12. Schalbart, P.; Kawaji, M. Comparison of paraffin nanoemulsions prepared by low-energy emulsification method for latent heat storage. Int. J. Therm. Sci. 2013, 67, 113-119. [CrossRef]

13. Puupponen, S.; Seppälä, A.; Vartia, O.; Saari, K.; Ala-Nissilä, T. Preparation of paraffin and fatty acid phase changing nanoemulsions for heat transfer. Thermochim. Acta 2015, 601, 33-38. [CrossRef]

14. Delgado-Sánchez, C.; Cuadri, A.A.; Navarro, F.J.; Partal, P. Formulation and processing of novel non-aqueous polyethylene glycol-in-silicone oil (o/o) phase change emulsions. Sol. Energy Mater. Sol. Cells 2021, 221, 110898. [CrossRef]

15. Yuan, Y.; Zhang, N.; Tao, W.; Cao, X.; He, Y. Fatty acids as phase change materials: A review. Renew. Sustain. Energy Rev. 2014, 29, 482-498. [CrossRef]

16. Ghadim, H.B.; Shahbaz, K.; Al-Shannaq, R.; Farid, M.M. Binary mixtures of fatty alcohols and fatty acid esters as novel solid-liquid phase change materials. Int. J. Energy Res. 2019, 43, 8536-8547. [CrossRef]

17. Zhang, Z.; Yuan, Y.; Zhang, N.; Cao, X. Thermophysical properties of some fatty acids/surfactants as phase change slurries for thermal energy storage. J. Chem. Eng. Data 2015, 60, 2495-2501. [CrossRef]

18. Fischer, L.; Mura, E.; O’Neill, P.; von Arx, S.; Worlitschek, J.; Qiao, G.; Li, Q.; Ding, Y. Thermophysical properties of a phase change dispersion for cooling around $50^{\circ} \mathrm{C}$. Int. J. Refrig. 2020, 119, 410-419. [CrossRef]

19. Fischer, L.; Mura, E.; O’Neill, P.; Von Arx, S.; Worlitschek, J.; Qiao, G.; Li, Q.; Ding, Y. Heat transfer performance potential with a high-temperature phase change dispersion. Energies 2021, 14, 4899. [CrossRef]

20. Li, Q.; Qiao, G.; Mura, E.; Li, C.; Fischer, L.; Ding, Y. Experimental and numerical studies of a fatty acid based phase change dispersion for enhancing cooling of high voltage electrical devices. Energy 2020, 198, 117280. [CrossRef]

21. Yin, D.; Ma, L.; Geng, W.; Zhang, B.; Zhang, Q. Microencapsulation of $n$-hexadecanol by in situ polymerization of melamineformaldehyde resin in emulsion stabilized by styrene-maleic anhydride copolymer. Arch. Thermodyn. 2015, 39, 661-667. [CrossRef]

22. Shang, Y.; Zhang, D. Preparation and thermal properties of graphene oxide-microencapsulated phase change materials. Nanoscale Microscale Thermophys. Eng. 2016, 20, 147-157. [CrossRef]

23. Wu, B.; Shi, L.; Zhang, Q.; Wang, W.J. Microencapsulation of 1-hexadecanol as a phase change material with reversible thermochromic properties. RSC Adv. 2017, 7, 42129-42137. [CrossRef]

24. Feczkó, T.; Trif, L.; Horák, D. Latent heat storage by silica-coated polymer beads containing organic phase change materials. Sol. Energy 2016, 132, 405-414. [CrossRef]

25. Wang, Y.; Li, X.; Shen, C.; Mao, Z.; Xu, H.; Zhong, Y.; Sui, X.; Feng, X.; Wang, B. Lignin assisted Pickering emulsion polymerization to microencapsulate 1-tetradecanol for thermal management. Int. J. Biol. Macromol. 2020, 146, 1-8. [CrossRef] [PubMed]

26. Li, H.; Jiang, M.; Li, Q.; Li, D.; Huang, J.; Hu, W.; Dong, L.; Xie, H.; Xiong1, C. Facile preparation and thermal performances of hexadecanol/crosslinked polystyrene core/shell nanocapsules as phase change material. Polym. Compos. 2014, 35, $2154-2158$. [CrossRef]

27. Zhang, X.; Niu, J.; Wu, J. yong Evaluation and manipulation of the key emulsification factors toward highly stable PCM-water nano-emulsions for thermal energy storage. Sol. Energy Mater. Sol. Cells 2021, 219, 110820. [CrossRef]

28. McClements, D.J. Nanoemulsions versus microemulsions: Terminology, differences, and similarities. Soft Matter 2012, 8, 1719-1729. [CrossRef]

29. Huang, L.; Doetsch, C.; Pollerberg, C. Low temperature paraffin phase change emulsions. Int. J. Refrig. 2010, 33, 1583-1589. [CrossRef]

30. Shao, J.; Darkwa, J.; Kokogiannakis, G. Development of a novel phase change material emulsion for cooling systems. Renew. Energy 2016, 87, 509-516. [CrossRef]

31. Safari, A.; Saidur, R.; Sulaiman, F.A.; Xu, Y.; Dong, J. A review on supercooling of phase change materials in thermal energy storage systems. Renew. Sustain. Energy Rev. 2017, 70, 905-919. [CrossRef]

32. Huang, L.; Günther, E.; Doetsch, C.; Mehling, H. Subcooling in PCM emulsions-Part 1: Experimental. Thermochim. Acta 2010, 509, 93-99. [CrossRef]

33. Cabaleiro, D.; Agresti, F.; Barison, S.; Marcos, M.A.; Prado, J.I.; Rossi, S.; Bobbo, S.; Fedele, L. Development of paraffinic phase change material nanoemulsions for thermal energy storage and transport in low-temperature applications. Appl. Therm. Eng. 2019, 159, 113868. [CrossRef] 
34. Agresti, F.; Fedele, L.; Rossi, S.; Cabaleiro, D.; Bobbo, S.; Ischia, G.; Barison, S. Nano-encapsulated PCM emulsions prepared by a solvent-assisted method for solar applications. Sol. Energy Mater. Sol. Cells 2019, 194, 268-275. [CrossRef]

35. Barison, S.; Cabaleiro, D.; Rossi, S.; Kovtun, A.; Melucci, M.; Agresti, F. Paraffin-graphene oxide hybrid nano emulsions for thermal management systems. Colloids Surf. A Physicochem. Eng. Asp. 2021, 627, 127132. [CrossRef]

36. Wang, F.; Liu, J.; Fang, X.; Zhang, Z. Graphite nanoparticles-dispersed paraffin/water emulsion with enhanced thermal-physical property and photo-thermal performance. Sol. Energy Mater. Sol. Cells 2016, 147, 101-107. [CrossRef]

37. Wang, F.; Zhang, C.; Liu, J.; Fang, X.; Zhang, Z. Highly stable graphite nanoparticle-dispersed phase change emulsions with little supercooling and high thermal conductivity for cold energy storage. Appl. Energy 2017, 188, 97-106. [CrossRef]

38. Zhang, X.; Niu, J.; Zhang, S.; Wu, J.Y. PCM in water emulsions: Supercooling reduction effects of nano-additives, viscosity effects of surfactants and stability. Adv. Eng. Mater. 2015, 17, 181-188. [CrossRef]

39. Zhang, X.; Niu, J.; Wu, J.Y. Development and characterization of novel and stable silicon nanoparticles-embedded PCM-in-water emulsions for thermal energy storage. Appl. Energy 2019, 238, 1407-1416. [CrossRef]

40. Zhang, G.; Yu, Z.; Cui, G.; Dou, B.; Lu, W.; Yan, X. Fabrication of a novel nano phase change material emulsion with low supercooling and enhanced thermal conductivity. Renew. Energy 2020, 151, 542-550. [CrossRef]

41. Fischer, L.J.; von Arx, S.; Wechsler, U.; Züst, S.; Worlitschek, J. Phase change dispersion properties, modeling apparent heat capacity. Int. J. Refrig. 2017, 74, 240-253. [CrossRef]

42. Fischer, L.J.; Von Arx, S.; Wechsler, U.; Züst, S.; Worlitschek, J. Phase change dispersion, potentially a new class of heat transfer fluids. J. Phys. Conf. Ser. 2016, 745, 032133. [CrossRef]

43. Huang, L.; Noeres, P.; Petermann, M.; Doetsch, C. Experimental study on heat capacity of paraffin/water phase change emulsion Energy Convers. Manag. 2010, 51, 1264-1269. [CrossRef]

44. Liu, L.; Niu, J.; Wu, J.Y. Formulation of highly stable PCM nano-emulsions with reduced supercooling for thermal energy storage using surfactant mixtures. Sol. Energy Mater. Sol. Cells 2021, 223, 110983. [CrossRef]

45. Lu, W.; Tassou, S.A. Experimental study of the thermal characteristics of phase change slurries for active cooling. Appl. Energy 2012, 91, 366-374. [CrossRef]

46. Huang, L.; Petermann, M.; Doetsch, C. Evaluation of paraffin/water emulsion as a phase change slurry for cooling applications. Energy 2009, 34, 1145-1155. [CrossRef]

47. Günther, E.; Huang, L.; Mehling, H.; Dötsch, C. Subcooling in PCM emulsions-Part 2: Interpretation in terms of nucleation theory. Thermochim. Acta 2011, 522, 199-204. [CrossRef]

48. Zhao, Q.; Yang, W.; Zhang, H.; He, F.; Yan, H.; He, R.; Zhang, K.; Fan, J. Graphene oxide Pickering phase change material emulsions with high thermal conductivity and photo-thermal performance for thermal energy management. Colloids Surf. A Physicochem. Eng. Asp. 2019, 575, 42-49. [CrossRef]

49. Zhang, X.; Wu, J.Y.; Niu, J. PCM-in-water emulsion for solar thermal applications: The effects of emulsifiers and emulsification conditions on thermal performance, stability and rheology characteristics. Sol. Energy Mater. Sol. Cells 2016, 147, 211-224. [CrossRef]

50. Wang, F.; Lin, W.; Ling, Z.; Fang, X. A comprehensive review on phase change material emulsions: Fabrication, characteristics, and heat transfer performance. Sol. Energy Mater. Sol. Cells 2019, 191, 218-234. [CrossRef]

51. Shao, J.; Darkwa, J.; Kokogiannakis, G. Review of phase change emulsions (PCMEs) and their applications in HVAC systems. Energy Build. 2015, 94, 200-217. [CrossRef]

52. Rinaldi, G.; Lazaro, A.; Delgado, M.; Marin, J.M.; Peñalosa, C.; Lozano, M.A.; Serra, L.M.; Verda, V. Study on seasonal and short-term thermal energy storage using a phase change material emulsion for district heating applications. In Proceedings of the ISES Solar World Conference 2017 and the IEA SHC Solar Heating and Cooling Conference for Buildings and Industry, Abu Dhabi, United Arab Emirates, 29 October-2 November 2017; pp. 771-782. [CrossRef]

53. Cao, J.; He, Y.; Feng, J.; Lin, S.; Ling, Z.; Zhang, Z.; Fang, X. Mini-channel cold plate with nano phase change material emulsion for Li-ion battery under high-rate discharge. Appl. Energy 2020, 279, 115808. [CrossRef]

54. Fedele, L.; Colla, L.; Bobbo, S.; Barison, S.; Agresti, F. Experimental stability analysis of different water- based nanofluids. Nanoscale Res. Lett. 2011, 6, 300. [CrossRef]

55. Hassan, P.A.; Rana, S.; Verma, G. Making sense of Brownian motion: Colloid characterization by dynamic light scattering Langmuir 2015, 31, 3-12. [CrossRef]

56. Cabaleiro, D.; Gracia-Fernández, C.; Lugo, L. (Solid + liquid) phase equilibria and heat capacity of (diphenyl ether + biphenyl) mixtures used as thermal energy storage materials. J. Chem. Thermodyn. 2014, 74, 43-50. [CrossRef]

57. Zeroual, S.; Estellé, P.; Cabaleiro, D.; Vigolo, B.; Emo, M.; Halim, W.; Ouaskit, S. Ethylene glycol based silver nanoparticles synthesized by polyol process: Characterization and thermophysical profile. J. Mol. Liq. 2020, 310, 113229. [CrossRef]

58. Hamze, S.; Berrada, N.; Cabaleiro, D.; Desforges, A.; Ghanbaja, J.; Gleize, J.; Bégin, D.; Michaux, F.; Maré, T.; Vigolo, B.; et al. Few-layer graphene-based nanofluids with enhanced thermal conductivity. Nanomaterials 2020, 10, 1258. [CrossRef]

59. Vijande, J.; Piñeiro, M.M.; García, J.; Valencia, J.L.; Legido, J.L. Density and surface tension variation with temperature for heptane + 1-alkanol. J. Chem. Eng. Data 2006, 51, 1778-1782. [CrossRef]

60. Cabaleiro, D.; Agresti, F.; Barison, S.; Rossi, S.; Bobbo, S.; Fedele, L. Synthesis and characterization of nano-PCM in water for phase-change secondary refrigerants applications. In Proceedings of the Refrigeration Science and Technology, International Institute of Refrigeration, Montreal, Canada, 24-30 August 2019; pp. 1965-1973. 
61. Nakarapanich, J.; Barameesangpet, T.; Suksamranchit, S.; Sirivat, A.; Jamieson, A.M. Rheological properties and structures of cationic surfactants and fatty alcohol emulsions: Effect of surfactant chain length and concentration. Colloid Polym. Sci. 2001, 279, 671-677. [CrossRef]

62. Colafemmina, G.; Palazzo, G.; Mateos, H.; Amin, S.; Fameau, A.L.; Olsson, U.; Gentile, L. The cooling process effect on the bilayer phase state of the CTAC/cetearyl alcohol/water surfactant gel. Colloids Surfaces A Physicochem. Eng. Asp. 2020, 597, 124821. [CrossRef]

63. Barry, B.W. The self bodying action of the mixed emulsifier sodium dodecyl sulfate/cetyl alcohol. J. Colloid Interface Sci. 1968, 28, 82-91. [CrossRef]

64. Ho, C.C.; Goetz, R.J.; El-Aasser, M.S. A biaxial lyotropic nematic phase in dilute solutions of sodium lauryl sulfate-1-hexadecanolwater. Langmuir 1991, 7, 630-635. [CrossRef]

65. Karl, W.; Perla, R.; Gérard, C.; Franck, C.; Luc, N.M.; Hayat, B.; Denis, F. Effect of surfactant on structure thermal behavior of cetyl stearyl alcohols: DSC and X-ray scattering studies. J. Therm. Anal. Calorim. 2016, 123, 1411-1417. [CrossRef]

66. Diniz, F.; Marques, C.; Barbosa, T.C.; Martins, D.; Nalone, L.; Costa, S.; Chaud, M.V.; da Silva, C.F.; Souto, E.B.; de Melo Barbosa, R.; et al. dPolymorphism, crystallinity and hydrophilic-lipophilic balance (HLB) of cetearyl alcohol and cetyl alcohol as raw materials for solid lipid nanoparticles (SLN). Asp. Nanotechnol. 2018, 1, 52-60. [CrossRef]

67. Lunardi, C.N.; Gomes, A.J.; Rocha, F.S.; De Tommaso, J.; Patience, G.S. Experimental methods in chemical engineering: Zeta potential. Can. J. Chem. Eng. 2021, 99, 627-639. [CrossRef]

68. Tang, B.; Wang, L.; Xu, Y.; Xiu, J.; Zhang, S. Hexadecanol/phase change polyurethane composite as form-stable phase change material for thermal energy storage. Sol. Energy Mater. Sol. Cells 2016, 144, 1-6. [CrossRef]

69. Métivaud, V.; Lefèvre, A.; Ventolà, L.; Négrier, P.; Moreno, E.; Calvet, T.; Mondieig, D.; Cuevas-Diarte, M.A. Hexadecane ( $\left.\mathrm{C}_{16} \mathrm{H}_{34}\right)$ +1-Hexadecanol $\left(\mathrm{C}_{16} \mathrm{H}_{33} \mathrm{OH}\right)$ binary system: Crystal structures of the components and experimental phase diagram. application to thermal protection of liquids. Chem. Mater. 2005, 17, 3302-3310. [CrossRef]

70. Shang, Y.; Zhang, D. Preparation and characterization of three-dimensional graphene network encapsulating 1-hexadecanol composite. Appl. Therm. Eng. 2017, 111, 353-357. [CrossRef]

71. Mosselman, C.; Mourik, J.; Dekker, H. Enthalpies of phase change and heat capacities of some long-chain alcohols. Adiabatic semi-microcalorimeter for studies of polymorphism. J. Chem. Thermodyn. 1974, 6, 477-487. [CrossRef]

72. Xing, J.; Tan, Z.C.; Shi, Q.; Tong, B.; Wang, S.X.; Li, Y.S. Heat capacity and thermodynamic properties of 1-hexadecanol. J. Therm. Anal. Calorim. 2008, 92, 375-380. [CrossRef]

73. Sosa, F.H.B.; Carareto, N.D.D.; Maximo, G.J.; Meirelles, A.J.D.A.; Costa, M.C. Solid-liquid equilibrium of binary systems containing fatty acids and fatty alcohols using differential scanning calorimetry. J. Chem. Eng. Data 2019, 64, 5017-5027. [CrossRef]

74. de Matos, F.C.; da Costa, M.C.; de Meirelles, A.J.; Batista, E.A.C. Binary solid-liquid equilibrium systems containing fatty acids, fatty alcohols and trilaurin by differential scanning calorimetry. Fluid Phase Equilib. 2016, 423, 74-83. [CrossRef]

75. Maximo, G.J.; Carareto, N.D.D.; Costa, M.C.; dos Santos, A.O.; Cardoso, L.P.; Krähenbühl, M.A.; Meirelles, A.J.A. On the solid-liquid equilibrium of binary mixtures of fatty alcohols and fatty acids. Fluid Phase Equilib. 2014, 366, 88-98. [CrossRef]

76. Acree, W.; Chickos, J.S. Phase transition enthalpy measurements of organic and organometallic compounds. Sublimation, vaporization and fusion enthalpies from 1880 to 2015. Part 1. C1-C10. J. Phys. Chem. Ref. Data 2016, 45, 033101. [CrossRef]

77. $\mathrm{Mu}, \mathrm{R}$.; Malhotra, V.M. Effects of surface and physical confinement on the phase transitions of cyclohexane in porous silica. Phys. Rev. B 1991, 44, 4296-4303. [CrossRef]

78. Gelb, L.D.; Gubbins, K.E.; Radhakrishnan, R.; Christenson, H.K. Confinement effects on freezing and melting. J. Phys. Condens. Matter 2001, 13, 95-133. [CrossRef]

79. Yang, L.; Liu, S.; Zheng, H. A comprehensive review of hydrodynamic mechanisms and heat transfer characteristics for microencapsulated phase change slurry (MPCS) in circular tube. Renew. Sustain. Energy Rev. 2019, 114, 109312. [CrossRef]

80. Lemmon, E.W.; Huber, M.L.; McLinden, M.O. NIST Standard Reference Database 23: Reference Fluid Thermodynamic and Transport Properties (REFPROP), Version 9.0. Physical and Chemical Properties. 2010. Available online: https://www.bibsonomy. org/bibtex/2ae369b98c7cc721f7e4eb576d6dee1e7/thorade (accessed on 28 November 2021).

81. Fu, Y.; Meng, X.; Liang, X.; Wu, J. Measurements of density and viscosity of 1-hexadecanol in the temperature range from (328.15 to 623.15) K at pressures up to $10 \mathrm{MPa}$. J. Chem. Thermodyn. 2021, 152, 106263. [CrossRef]

82. Macosko, C.W. Rheology. Principles, Measurements and Applications; Wiley-VCH: Weinheim, Germany, $1994 ;$ ISBN 1560815795.

83. Vogel, $\mathrm{H}$. The law of the relation between the viscosity of liquids and the temperature. Phys. Z. 1921, 22, $645-646$.

84. Fulcher, G.S. Analysis of recent measurements of the viscosity of glasses. J. Am. Ceram. Soc 1925, 8, 339-355. [CrossRef]

85. Tammann, G.; Hesse, W. The dependence of viscosity upon the temperature of supercooled liquids. Z. Anorg. Allg. Chem. 1926, 156, 245-257. [CrossRef]

86. Huang, X.; Alva, G.; Liu, L.; Fang, G. Microstructure and thermal properties of cetyl alcohol/high density polyethylene composite phase change materials with carbon fiber as shape-stabilized thermal storage materials. Appl. Energy 2017, 200, 19-27. [CrossRef]

87. Atinafu, D.G.; Dong, W.; Wang, C.; Wang, G. Synthesis of porous carbon from cotton using an $\mathrm{Mg}(\mathrm{OH})_{2}$ template for formstabilized phase change materials with high encapsulation capacity, transition enthalpy and reliability. J. Mater. Chem. A 2018, 6, 8969-8977. [CrossRef]

88. Maxwell, J.C. A Treatise on Electricity and Magnetism, 3rd ed.; Oxford University Press: London, UK, 1882. 
89. Hashin, Z.; Shtrikman, S. A Variational approach to the theory of the effective magnetic permeability of multiphase materials. J. Appl. Phys. 1962, 33, 3125-3131. [CrossRef]

90. Kawanami, T.; Togashi, K.; Fumoto, K.; Hirano, S.; Zhang, P.; Shirai, K.; Hirasawa, S. Thermophysical properties and thermal characteristics of phase change emulsion for thermal energy storage media. Energy 2016, 117, 562-568. [CrossRef]

91. Lenahan, F.D.; Zikeli, M.; Rausch, M.H.; Klein, T.; Fröba, A.P. Viscosity, interfacial tension, and density of binary-liquid mixtures of $n$-hexadecane with $n$-octacosane, 2,2,4,4,6,8,8-heptamethylnonane, or 1-hexadecanol at temperatures between 298.15 and 573.15 K by Surface Light Scattering and Equilibrium Molecular Dy. J. Chem. Eng. Data 2021, 66, 2264-2280. [CrossRef] 